\title{
On the Optimal Tilt Angle and Orientation of an On-Site Solar Photovoltaic Energy Generation System for Sabah's Rural Electrification
}

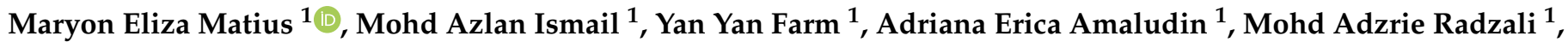 \\ Ahmad Fazlizan ${ }^{2}$ (D) and Wan Khairul Muzammil 1,*D \\ 1 Faculty of Engineering, Universiti Malaysia Sabah, Jalan UMS, Kota Kinabalu 88400, Malaysia; \\ MK1921047T@student.ums.edu.my (M.E.M.); lanz_mr@ums.edu.my (M.A.I.); yanyan@ums.edu.my (Y.Y.F.); \\ adriana@ums.edu.my (A.E.A.); mohdadzrie@ums.edu.my (M.A.R.) \\ 2 Solar Energy Research Institute, Universiti Kebangsaan Malaysia, Bangi 43600, Malaysia; \\ a.fazlizan@ukm.edu.my \\ * Correspondence: khairulm@ums.edu.my; Tel.: +88-320000 (ext. 3093)
}

check for updates

Citation: Matius, M.E.; Ismail, M.A.; Farm, Y.Y.; Amaludin, A.E.; Radzali, M.A.; Fazlizan, A.; Muzammil, W.K. On the Optimal Tilt Angle and Orientation of an On-Site Solar Photovoltaic Energy Generation System for Sabah's Rural Electrification. Sustainability 2021, 13, 5730. https://doi.org/10.3390/ su13105730

Academic Editors: Nuria

Novas Castellano and Rosa María García Salvador

Received: 7 April 2021

Accepted: 12 May 2021

Published: 20 May 2021

Publisher's Note: MDPI stays neutral with regard to jurisdictional claims in published maps and institutional affiliations.

Copyright: (c) 2021 by the authors. Licensee MDPI, Basel, Switzerland. This article is an open access article distributed under the terms and conditions of the Creative Commons Attribution (CC BY) license (https:/ / creativecommons.org/licenses/by/ $4.0 /)$.

\begin{abstract}
An ongoing project to implement a mini standalone solar photovoltaic (PV) generation system of $2.5 \mathrm{kWp}$ capacity at the eco-tourism centre of Liogu Ku Silou-Silou (EPLISSI), Sabah, was initiated in 2019. Since the solar panel support (ground mounting) used in this project will be erected separately, the main goals of this study are to estimate the optimum tilt angle, $\beta_{\text {opt }}$, and orientation for the solar PV modules. To achieve these goals, the Liu and Jordan isotropic diffuse radiation model was used (1960). Another three isotropic diffuse sky radiation models (Koronakis model, Badescu model, and Tian model) were applied to estimate the optimum tilt angle with the orientation kept facing due south. For verification purposes, the PV power output data obtained from an online PV simulator known as Global Solar Atlas or GSA 2.3 was used and compared to the results of the four isotropic models. The results suggest that the Tian model is more suitable for approximating insolation, as it was proven to have the lowest difference among all models and is in close agreement with the result of the optimum tilt angle provided by GSA 2.3. However, the outcomes demonstrated from the isotropic models propose an error up to $30 \%$ (in the range of $31 \%$ to $32 \%$ ) as compared to
\end{abstract} GSA 2.3.

Keywords: solar energy; solar radiation; photovoltaic system; insolation; tilt angle; orientation; isotropic models; Malaysia

\section{Introduction \\ 1.1. Research Background}

In terms of a country's development, the electricity use rate could signify how well developed the country is [1,2]. This, however, is not applied to the Organization for Economic Cooperation and Development (OECD) countries (i.e., the United States, Japan, and the United Kingdom), focusing on service economies rather than manufacturing economies [2]. According to [3], the global demand for electricity in 2018 rose by 4\%, and it is at its fastest pace since 2010. To meet the rising electrical demand, non-renewable energy sources such as coal and natural gas have been used as the primary sources for the power generation system, representing nearly $60 \%$ of the global electricity supply [4]. However, researchers from all over the world are putting in continuous efforts to develop renewable technology. This is an effort to discover a worthy substitute for fossil fuels. They are the world's most significant culprit of triggering global warming and responsible for causing a high uncertainty of alarming climate changes [5]. Through various uses of renewable energy technologies, and judging from the current capability of this type of energy source as stated by Gielen [6], it can be implied that renewable technologies are 
here to stay and expand even more. With a higher adoption rate, this will push the cost to own these technologies down [3]. Soon, there is no doubt that renewable technology will be the primary source of electricity, offering hope for a cleaner and better environment.

According to the International Energy Agency [4], it is reported that the percentage of renewables in global electricity generation had increased by $2 \%$, from $26 \%$ in the first quarter of 2019 to $28 \%$ in the first quarter of 2020. Solar energy is the main contributor to the increase of renewable shares compared to other renewable energy sources. Its growth in April 2020 was recorded up to $16 \%$, followed by wind energy, by $12 \%$. The report also highlighted that the increase happened after more than $100 \mathrm{GW}$ of solar PV and about $60 \mathrm{GW}$ of wind projects were completed in 2019. The solar energy industry can be divided into two different categories: the solar thermal and solar photovoltaic (PV) industries $[7,8]$. According to $[9,10]$, the term "photovoltaic" refers to a semiconductor-based device used to convert solar energy (sunlight) into electrical DC energy.

In contrast, the solar thermal system is used to heat water or air by first capturing solar radiation using vacuum tubes or perforated vertical tubes [11]. To generate electricity, the solar PV generation system has become a mainstream option. Its market has vastly expanded in a short period [12], where according to Parikh [13], 70\% of solar PV module manufacturing is accounted for by China. However, authors in [14] emphasised that solar PV's electricity production time could be prolonged using a thermal energy storage system, by charging the thermal energy storage systems at the peak of solar energy during the day, and using the stored heat at night-time. This shows that although the thermal energy storage system is one of the systems that has been less developed, it still can play an essential role in the power generation system [10,15].

Utilising the energy contained in the sunlight and identified as the cleanest renewable energy source, solar PV generation system can be broken down into three main types: standalone system, grid-connected system, and hybrid system [16]. In Malaysia, the standalone solar PV system is mainly installed in remote rural areas [17]. Being surrounded by uneven terrain and dense jungles [18], and also due to economic constraints [19], gridconnected and hybrid systems are not feasible in these areas at present. As its name suggests, the standalone system relies solely on solar power, and can be designed so that it only consists of PV modules and load, or with an addition of batteries and the necessary components and accessories for energy storage $[8,20,21]$.

\subsection{Literature Review}

The solar PV system can only be installed in areas where there is enough direct supply of solar energy so that the financial investment becomes worthy [22]. Fortunately, Malaysia is located within the second largest solar radiation region globally, between 1 degree and 7 degrees in north latitude and 100 degrees and 120 degrees in east longitude [16]. Malaysia's potential for solar power generation is estimated at four times the world fossil fuel resources, since there is an average of 4 to $8 \mathrm{~h}$ of sunshine every day [11,23,24]. Authors in [18] remarked that the abundance of solar radiation averaging from 4.8 to $6.1 \mathrm{kWh} / \mathrm{m}^{2} /$ day indicates a high potential for solar energy throughout this country. Furthermore, as seen in Figure 1, the photovoltaic power potential in several places in Malaysia exceeded daily totals of $4.0 \mathrm{kWh} / \mathrm{kWp}$ [25]. In another study [19], the authors have stated that there is a massive potential of solar energy system resources in electricity generation. Hence, they concluded that the installation of a solar energy system is highly feasible in Malaysia. 


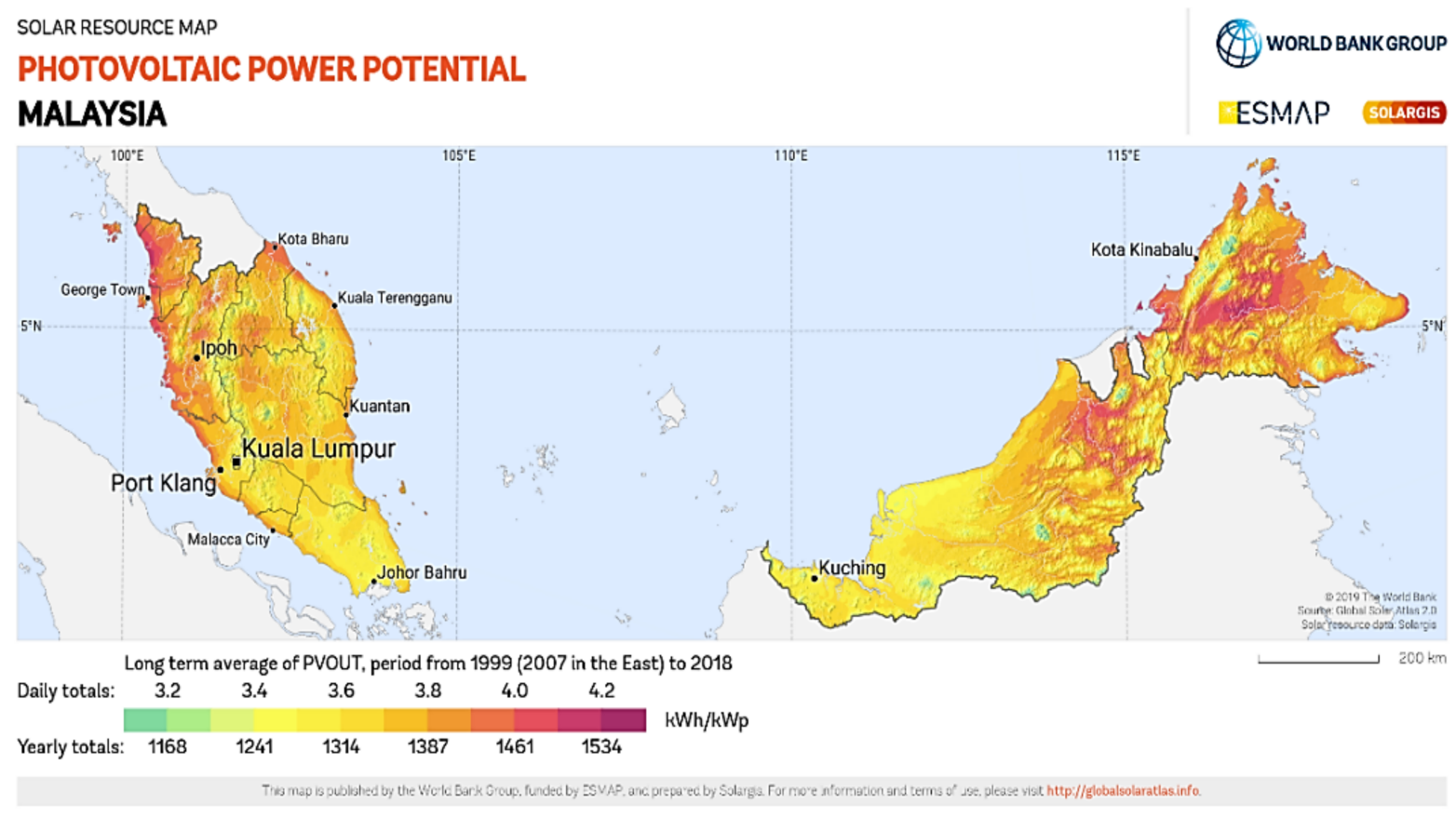

Figure 1. Malaysia's photovoltaic power potential map obtained from the Global Solar Atlas 2.0, a free, web-based application that is developed and operated by the company Solargis s.r.o. on behalf of the World Bank Group, utilising Solargis data, with funding provided by the Energy Sector Management Assistance Program (ESMAP). For additional information: https:/ /globalsolaratlas.info (accessed on 20 November 2020) [26].

On the other hand, a complete working solar PV system is still considered expensive at present $[27,28]$; however, the average cost of energy (COE) is experiencing a downward trend and is currently cheaper than fossil fuel power plants. Therefore, it is crucial for the maximum amount of sunlight to be captured by the solar PV module. Indirectly, this also helps avoid oversizing the solar PV system and ensuring that it operates efficiently [29]. Hence, to have maximum PV power output, two essential factors, namely, optimum tilt angle and solar PV modules orientation, are crucial for designing and installing solar PV panels. In a study conducted by [30], the authors stated that adjusting the PV module's tilt angle in different seasons causes more energy to be captured. The sunlight intensity is different according to the season and location, that is, the latitude and longitude, season, local landscape, and local weather [31]. This statement further indicated that the optimum tilt angle and orientation would be different at different times and locations [32]. Hence, this indirectly led to diverse methods being established and developed to determine the maximum solar radiation factors.

\section{Solar Models}

The method of obtaining the total solar irradiation is done by initially estimating the ratio of diffuse components on a tilted surface to a horizontal surface, which can be classified into two general models known as isotropic and anisotropic models. According to Shukla [33], there are three components of the diffused fraction of radiation on tilted surfaces, comprised of isotropic, circumsolar, and horizon brightening factors. For the isotropic-type models, the intensity of diffuse sky radiation is assumed as uniform over the skydome. Some examples of isotropic models are the Liu and Jordan model, the Koronakis model, the Badescu model, the Tian model, and the Jimenez and Castro model. In comparison, the anisotropic-type model assumes the anisotropy of the diffuse sky radiation in the circumsolar region, as well as the isotropically distributed diffuse component from the rest of the skydome, which is the horizon brightening fraction. Models such as the Temps-Coulson model, Steven and Unsworth model, Hay model, Klucher model, and Gueymard model are examples of anisotropic-type models [33-35]. 
Several past research projects have been conducted to obtain a solar collector's optimum tilt angle using both the isotropic and anisotropic models and other models. Hailu [34] conducted a study to identify the optimum tilt angle and orientation of a solar module that maximises solar irradiation. The study applied eight empirical models (four isotropic and four anisotropic models) in Canada. As a result, it was found that the anisotropic models were more consistent as compared to isotropic models with varying optimum tilt angles in the range of $46^{\circ}$ to $47^{\circ}$ and $37^{\circ}$ to $44^{\circ}$, respectively. The results also suggest that the collector's tilt angle should be changed four times over a year to receive more solar radiation. The solar module orientation should be installed with a flatter tilt angle facing west or east due south.

Apart from that, Shukla [33] conducted a study to compare different empirical models' accuracy by using six empirical models (three isotropic and three anisotropic models) at Bhopal, India. This was done by comparing the empirical models' results with the ground-measured data from one sample statistical test. The tilt angle was fixed to Bhopal's latitude, $23.26^{\circ}$, and the orientation was also fixed facing due south. The results indicate that among all models, an isotropic model known as the Badescu model possessed minor statistical errors. This model was more suitable for the estimation of solar radiation incident on a tilted surface. Authors in [36] conducted a study to determine the optimum tilt angle and orientation of the PV module by applying the harmony search (HS) metaheuristic algorithm method in six different places in China. The result has shown that the optimum tilt angle will differ at all the different places; hence, it should be changed once a month, and the PV module is best oriented to face due south. Besides, in a study done by Abdallah [27], a mathematical model was used to estimate the solar radiation on south-facing surfaces with different tilt angles in Palestinian cities. This model has been verified by the Photovoltaic Geographical Information System (PVGIS) and Photovoltaic Software (PVWatts) developed by the NREL. The results show that most Palestinian cities' annual optimum tilt angle is around 29 degrees, showing a 10\% energy gain compared to a solar panel mounted on a horizontal surface.

Meanwhile, Hertzog [37] conducted a study to find the optimum tilt angle of a fixed PV module that was mounted in South Africa by running an experiment. In this study, an experimental design incorporating a two-year longitudinal study was used. The outcome shows that in 2016 and 2017, a PV module with a tilt angle of latitude $+10^{\circ}$ and a PV module with a tilt angle of latitude $-10^{\circ}$ yielded the highest output power for winter months and summer months, respectively. However, it is recommended to install the collector at a tilt angle equal to the latitude, as it will cause the highest overall average output power to be yielded. In another study conducted by [38], a mathematical model was used to estimate solar radiation and determine the optimum tilt angle and orientation on a tilted surface. This was done in the high latitudes zone in the Southern Hemisphere, where the method was applied for a specific period and on a daily basis. By positioning the collector monthly at an optimum tilt angle, this achieves a yearly gain in solar radiation up to 1.8 times compared to the case of a horizontal surface.

For research that has been conducted explicitly in Malaysia: authors in [39] conducted a study to optimise the tilt angle of the photovoltaic module installed in five sites, namely, Kuala Lumpur, Ipoh, Alor Setar, Johor Bharu, and Kuching, by using the Liu and Jordan model. The results indicate that for states that are in Peninsular Malaysia, an optimum seasonal tilt is recommended. For states in East Malaysia, a monthly change of tilt angle will help the PV modules capture the maximum amount of solar radiation. Apart from that, the authors in [40] conducted a study to assess the solar radiation on variously oriented surfaces and optimum tilts for a solar collector in Bangi, of latitude 3 degrees north. Seven years' worth of monthly average daily solar radiation on the horizontal plane was used as an input for the KT solar radiation model and simulated using MATLAB to provide solar irradiation data at various orientations for the whole year. The result shows that the monthly optimum tilt angle changed throughout the year, ranging from $-24^{\circ}$ (facing due south) to $+22^{\circ}$ (facing due North). Meanwhile, the annual optimum tilt angle is close to 
Bangi's latitude, which is $1.4^{\circ}$ facing due south, while the optimum angles for seasonal south- and north-facing surfaces were found to be $14.4^{\circ} \pm 5^{\circ}$ and $14.8^{\circ} \pm 5^{\circ}$, respectively. Lastly, a study conducted by [41] intended to evaluate the fixed optimum tilt angle of PV panels at three rural villages, namely Kampung Opar (Sarawak, Malaysia), Kampung Labi (Beaufort, Sabah, Malaysia), and Kampung Orang Asli Kemendol (Selangor, Malaysia). The Liu and Jordan model is applied in this study, and the result has shown that the optimal tilt angle in these three locations is under $5^{\circ}$. A summary of other past research is tabulated in Table 1.

Table 1. Previous research regarding the optimum tilt angle in Malaysia.

\begin{tabular}{|c|c|c|c|c|c|c|}
\hline Papers & Case Study & $\begin{array}{c}\text { Monthly Optimum } \\
\text { Angle }\end{array}$ & Optimum Fixed Tilt Angle & Applied Tool & Method & Orientation of PV \\
\hline $\begin{array}{l}\text { Khatib, } \\
\text { Mohamed, } \\
\text { Mahmoud, } \\
\text { Sopian [39] }\end{array}$ & $\begin{array}{c}\text { Kuala Lumpur, } \\
\text { Ipoh, Alor Setar, } \\
\text { Johor Bharu, and } \\
\text { Kuching }\end{array}$ & Provided & latitude of the location & Excel & Liu and Jordan & South \\
\hline $\begin{array}{l}\text { Khai, Nor } \\
\text { Mariah, } \\
\text { Othman, Mohd } \\
\text { Zainal [40] }\end{array}$ & Bangi & Provided & $\begin{array}{c}14.4^{\circ} \pm 5^{\circ} \text { and } \\
14.8^{\circ} \pm 5^{\circ} \text {-latitude of the } \\
\text { location }\end{array}$ & MATLAB & $\begin{array}{l}\text { KT solar radiation } \\
\text { model }\end{array}$ & $\begin{array}{l}\text { Facing south and } \\
\text { north }\end{array}$ \\
\hline Muhida [42] & Kuala Lumpur & - & $1^{\circ}$ to $15^{\circ}$ & Solar Pro & - & No difference \\
\hline Sunderan [43] & Ipoh, Perak & Provided & $\begin{array}{c}0^{\circ} \text { or tilt angle-latitude of } \\
\text { the location }\end{array}$ & - & $\begin{array}{l}\text { Collares-Pereira } \\
\text { and Rabi }\end{array}$ & $\begin{array}{l}\text { Facing south and } \\
\text { north }\end{array}$ \\
\hline Elhassan [44] & Kuala Lumpur & - & $15^{\circ}$ to $30^{\circ}$ & $\begin{array}{l}\text { PVSYS-50, Excel, } \\
\text { MATLAB }\end{array}$ & - & East, north \\
\hline Daut [45] & Perlis & Provided & - & - & - & - \\
\hline Khatib [46] & Kuala Terengganu & Provided & $0^{\circ}$ to $23^{\circ}$ & MATLAB & Liu and Jordan & - \\
\hline Omidreza [47] & Kuala Lumpur & - & $10^{\circ}$ & Excel & Cooper's equation & - \\
\hline
\end{tabular}

These previous studies have shown different methods that can demonstrate reliable results. Based on the literature review, the estimation process of the optimal tilt angle and the optimal orientation of solar PV modules are needed as part of the solar PV energy system's design process. Without an optimal tilt angle and orientation, this will be considered a loss, as the solar PV system's efficiency is not brought up to the maximum. Furthermore, if this process is skipped, it will cause an over-sizing of the whole complete solar PV system design. Consequently, money will be wasted, and investors will experience losses using this system compared to any other alternatives. Therefore, it will be better to include the design process and obtain the optimum tilt and orientation for a more economical and effective design.

\subsection{Study Contribution}

For sustainable electrical energy development in a specific area of Kinabalu Geopark (Sabah), a project to implement a mini standalone solar PV generation system was initiated. Based on the evaluation of the solar radiation potential of the surrounding area of the Kinabalu Geopark, it was found that the surrounding region has outstanding potential for the implementation of solar energy projects with high potential daily yield (approximately $3.816 \mathrm{kWh} / \mathrm{kWp}$ ). The Eco-Tourism centre of Liogu Ku Silou-Silou, known as EPLISSI, located within Kinabalu Geopark, was selected as the solar energy system installation site. It is a community-based tourism (CBT) centre located in Kampung Koung Malaan, Kota Belud, under the Kadamaian Tourism Association's auspices (KATA).

Preliminary data on the load demand was recorded during a visit conducted to EPLISSI after consent was granted to run the project by the EPLISSI's manager. The outcome stated that EPLISSI was indeed a suitable and strategic location for installing a solar PV system. Figure 2 illustrates the layout of EPLISSI's surrounding area. 


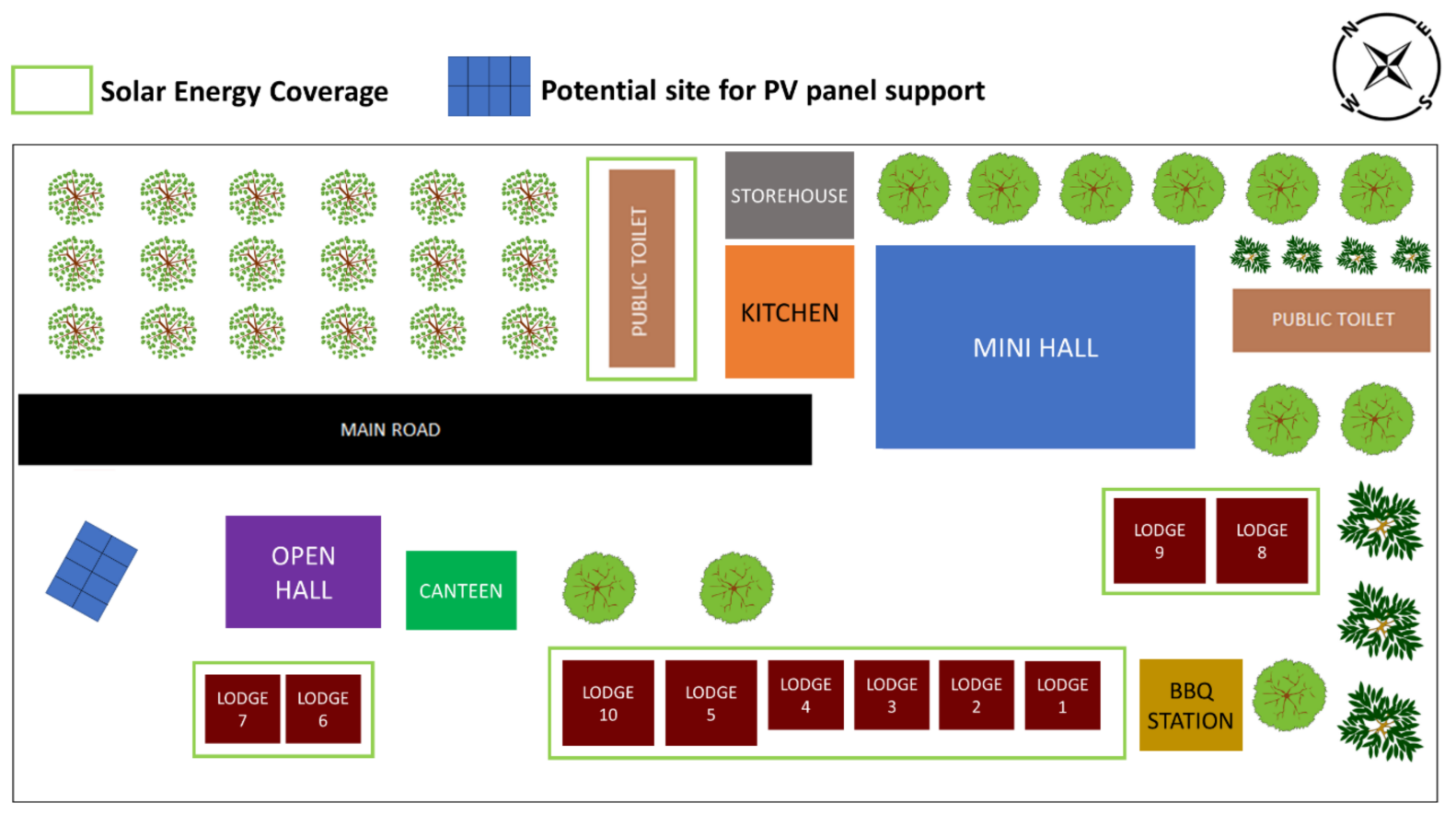

Figure 2. The layout of EPLISSI's surrounding area.

The pre-selected buildings under solar electricity coverage are marked inside the green box, including a public toilet and ten lodges. The total daily peak and average load demands of the pre-selected buildings are shown in Table 2.

Table 2. Total average daily energy used (data from August to October 2019).

\begin{tabular}{cc}
\hline Type of Demand & Energy Used, $\mathbf{k W h}$ \\
\hline Total peak demand & 11.874 \\
Total average demand & 4.600 \\
\hline
\end{tabular}

Furthermore, the data obtained through this visit was vital to this study, which needs to be focused on the design of a suitable supporting frame for the solar PV module installation. Through observation and assessments made on all the existing buildings in EPLISSI, it was concluded that their constructions are not suitable. The sturdiness of the buildings was deemed insufficient for the installation of solar modules. Moreover, all the buildings are located near trees, which can cause an issue known as the shadow effect. According to [48], the drawbacks of the shadow's effect on PV panels reduce the PV power output, and this could cause a hazardous situation. Hence, the shadow effect should be avoided, and the installation site should be located away from trees. These reasons have led to a decision requiring a separate solar PV module support structure to be erected. Hence, the objectives of this study are:

1. To find the optimum tilt angle, $\beta_{\text {opt }}$, and the orientation of the solar PV modules at EPLISSI that could provide the maximum monthly insolation, $H$, throughout the year by applying the Liu and Jordan isotropic diffuse sky radiation model; and to identify the suitable tilt angle and orientation by using the Liu and Jordan empirical model with the variation of conditions listed as follows:

- The collector's orientation is kept in facing due south position throughout the year.

- $\quad$ Both the tilt angle and orientation could be adjusted throughout the year.

- $\quad$ Both tilt angle and orientation (facing due south) are fixed. 
2. To find the optimum tilt angle, $\beta_{\mathrm{opt}}$, at EPLISSI by applying four isotropic models known as the Liu and Jordan, Koronakis, Badescu, and Tian models and identifying the highest solar irradiation value. The orientation is fixed facing due south. The results of total PV power output found through each of the models will be compared to results simulated using Global Solar Atlas version 2.3 or GSA 2.3 to determine the most preferred model to estimate the total solar irradiance in EPLISSI.

\section{Methodology}

To meet this study's objectives, specific methodologies were applied to ensure that the data acquired were sufficient. Section 2.1 will explain more regarding the location and surrounding area of EPLISSI. Meanwhile, the data source and the model used by GSA 2.3 to simulate the PV power output will be expounded in Section 2.2. The process of approximating the total solar irradiance, insolation, and total PV power output by applying the Liu and Jordan isotropic diffuse sky radiation model will be explicated in Section 2.3. Lastly, in Section 2.4, the formula used to calculate the diffuse component of radiation, and the Liu and Jordan, Koronakis, Badescu, and Tian isotropic models will be discussed. All calculations are made using Microsoft Excel 2019.

\subsection{Study Location}

The eco-tourism centre is in the district of Kota Belud, Sabah, Malaysia. The distance between Kota Belud town and EPLISSI is about $15 \mathrm{~km}$. The geographical location of EPLISSI lies within north latitude $06^{\circ} 15^{\prime} 08^{\prime \prime}$, east longitude $116^{\circ} 27^{\prime} 50^{\prime \prime}$, and elevation $75 \mathrm{~m}$ above sea level. Cropland, trees, and water cover the surrounding area. Over the year, the temperature usually fluctuates from $23{ }^{\circ} \mathrm{C}$ to $32{ }^{\circ} \mathrm{C}$ and is seldom below $22{ }^{\circ} \mathrm{C}$ or above $34{ }^{\circ} \mathrm{C}$ [49]. Humidity is always high, from about 70\% to $90 \%$ [50]. The eco-tourism centre is located near a river and sits deep within a valley. Due to this challenging tropical terrain, it is incredibly challenging to lay electrical cables to connect to the main national grid, as the cost will be extraordinarily high. Besides, it will also be quite risky due to the high possibility of massive flooding, bringing hazard to the surrounding community.

\subsection{Global Solar Atlas PV Data Simulator}

The theoretical result, specifically the photovoltaic (PV) power output data calculated using four isotropic models, that is, the Liu and Jordan, Koronakis, Badescu, and Tian models, will be validated and compared to the data provided by a PV power potential simulator known as Global Solar Atlas version 2.3 or GSA 2.3 (fifth version released in July 2020). GSA 2.3 is an online application produced by Solar Geographic Information System, or simply Solargis, under a contract with The World Bank and funded by the Energy Sector Management Assistance Program (ESMAP). In January 2017, the first version of Global Solar Atlas (GSA), known as GSA 1.0, was released with the primary purpose of offering access to solar resources and photovoltaic power potential data globally.

As shown in Figure 3 below, there are three main different calculation models used by GSA 2.3: the solar radiation model, air temperature model, and PV power simulation model. To compute the solar resource parameters, the data inputs from geostationary satellites and meteorological models are used. Other than the solar radiation, air temperature and PV modules' temperature are the crucial secondary component data for the solar electricity simulation. 


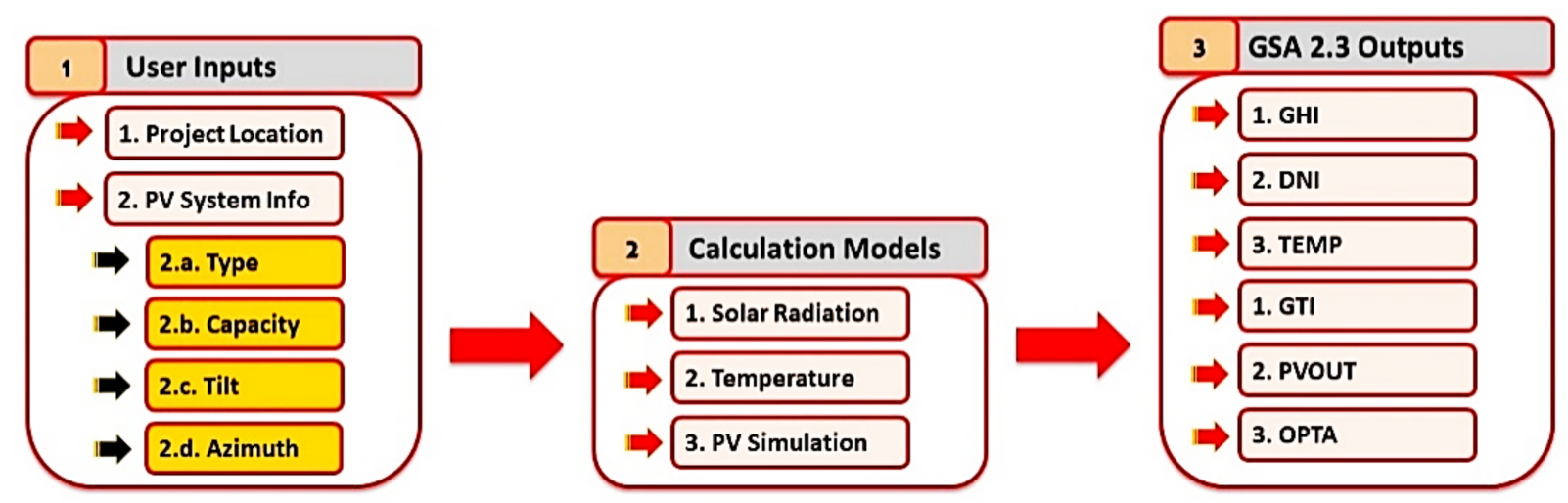

Figure 3. Global Solar Atlas online application.

The modelling of solar radiation of GSA 2.3 is based on the Solargis model, which uses the most modern input data from satellite and atmospheric conditions [51]. In the Solargis model, data gathered from satellites are used to detect cloud properties using advanced algorithms. Hence, this approach is efficient to replicate as well as reproduce real circumstances. Apart from that, results from operational numerical weather models (NWP) are used for forecast data; in the post-processing stage, operationally computed data from the satellite model is applied for dynamic improvement of the precision of the prediction. The solar radiation retrieval in the Solargis satellite-to-irradiance model is divided into three phases:

1. The clear-sky irradiance (the irradiance touching the ground with the assumption of lack of clouds) is computed using the clear-sky model.

2. The satellite data (data from several geostationary satellites) quantifies the attenuation effect of clouds through cloud index computation. The clear-sky irradiance is combined with the cloud index to retrieve all-sky irradiance. This process results in direct normal irradiance (DNI) and global horizontal irradiance (GHI).

3. The DNI and GHI are utilised for computing diffuse and global tilted irradiance (irradiance in plane of the array, on tilted or tracking surfaces) and/or irradiance rectified for shading effects from surrounding terrain or nearby objects.

For the air temperature model in GSA 2.3 (or, as a result, the temperature of PV modules), meteorological parameters are essential. The meteorological data at a specific location used in this model are gathered by either measuring them from a well-maintained meteorological station with high-standard instruments or deriving them from meteorological models. The meteorological data for global models have lower spatial and temporal resolution compared to solar-resource-modelled data. Hence, it has to be post-processed in order to deliver parameters with local representation.

Meanwhile, in the PV power simulation model, for every location chosen by the user, the multi-year, sub-hourly time series of solar radiation and air temperature data from Solargis are utilised as input for the computations of the photovoltaic power generation. Based on the original Solargis full-time series of data, statistically gathered data is precomputed. For each month, a series of 7 percentile days in a $15 \mathrm{~min}$ time step is generated. After the simulation is made, to represent the range of estimated conditions for each location each month, a weighted average provides the final long-term monthly and annual results.

In this study, GSA 2.3 is mainly utilised to provide the PV power output data. Simultaneously, the terrain elevation data is used in the theoretical calculation to represent the terrain elevation, $z$ in Equation (12). GSA 2.3 is a useful tool that can also be used to provide other location-specific information, including the global horizontal irradiation (GHI), the direct normal irradiation (DNI), the temperature of the air, the optimum tilt of PV modules, and also the global tilted irradiation at an optimum angle (GTI). Apart from that, as the solar project at EPLISSI will be considering a PV system size of $2.5 \mathrm{kWp}$ (sufficient to satisfy the load demand), a small residential configuration is selected for 
simulation of a roof-mounted PV system on the GSA 2.3 "PV power calculator" table. By selecting this arrangement, the assumptions of the system are as follows:

- Inadequate ventilation of PV modules mounted on roofs is considered; hence the output will be reduced due to the higher temperature of modules.

- The roof systems are usually installed at a sub-optimal inclination, which means that the access for cleaning is limited, thus increased collection of dust and soiling on modules is likely to happen.

- Cabling paths are short, directly linked into inverters (no combiner boxes), and generated AC power is evacuated into the grid directly from the inverter without a transformer.

- The availability is reduced because detailed monitoring systems are rarely utilised, and repair service in case of a failure may last several days.

In a study conducted by Ineichen [52], the GHI and DNI data provided by Solargis and another five satellite irradiance models have been compared to a high-quality measurement with about 16 years of continuous measurements in 18 locations. As a result, Solargis has been identified as the most accurate data source with the lowest overall bias, lowest rootmean-square deviation (RMSD), and lowest mean bias deviation. Hence, in terms of accuracy, the PV power outputs obtained from GSA 2.3 are highly reliable, as the solar data used are supported by Solargis. Further details concerning GSA 2.3 can be found from the Global Solar Atlas [53] and Solar Geographical Information System [54] websites.

\subsection{The Application of the Liu and Jordan Isotropic Diffuse Sky Radiation Model to Estimate the Optimal Tilt Angle and Orientation of the Solar Photovoltaic Module}

The optimum tilt angle and solar PV module orientation are among the critical factors that solar PV system designers need to focus on to maximise the total irradiance captured on the module's surface. In this study, the Liu and Jordan isotropic diffuse sky radiation model will be applied to estimate EPLISSI's optimal tilt angle and solar PV modules orientation. As mentioned, through the knowledge of solar geometry, this section will explain the process of obtaining the total solar irradiance, $I_{\text {tot }}$, and insolation, $H$, numerically, before estimating the optimum tilt angle, $\beta_{\mathrm{opt}}$, and the orientation (related to the azimuth angle of the normal to the collector surface, $\alpha_{2}$ ). To obtain the solar PV module's optimum tilt angle and the orientation at the installation location, the process to identify the optimum tilt angle, $\beta_{\mathrm{opt}}$, and orientation (related to $\alpha_{2}$ ) is explicated below. Meanwhile, to simplify the phases or steps above, Figure 4 will help illustrate the process workflow.

- $\quad$ Phase 1

Obtain and gather the information regarding the day number of year, $N$, where $N=1$ for 1st of January and $N=365$ for 31st of December (12 days are selected to represent each month for yearly analysis; the 21st day of each month is selected in this study); apparent solar irradiation, $A$, of the selected day; atmospheric extinction coefficient, $B$, of the selected day; ratio of diffuse radiation on a horizontal surface to direct normal irradiation, $C$, of the selected day (day -21st of each month); location's coordinates, latitude, L, and longitude, Long; location's elevation, $z$; and location's local standard time meridian, LSTM (based on longitude). 


\section{Phase 1:}

Obtain and gather the information of $N, A, B, C, L$, Long, $z$, and LSTM. Based on the location's latitude, $L$ also gather the data regarding its $\alpha_{2}$ and select the variation of angle for testing variable of $\beta_{2}$.

Phase 2:
Gather the information regarding azimuth angle of the
normal to the collector surface, $\alpha_{2}$. The collector tilt angle,
$\beta_{2}$ will act as the testing variable.

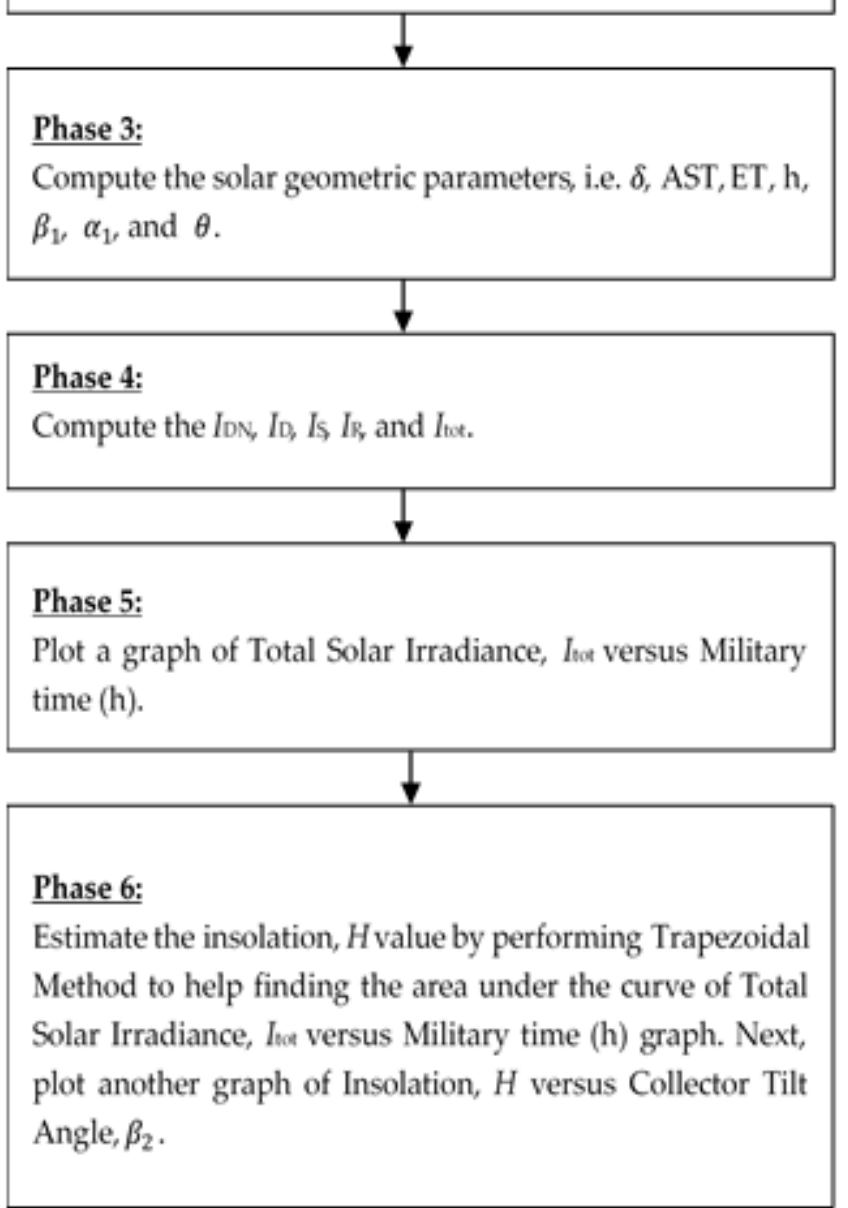

Figure 4. Process workflow of obtaining the solar PV module's optimum tilt angle and orientation.

\section{- $\quad$ Phase 2}

Based on the location's latitude, $\mathrm{L}$, gather the information regarding its azimuth angle of the normal to the collector surface, $\alpha_{2}$, and the collector tilt angle, $\beta_{2}$ (testing variable), is varied to be at least 15 ( 17 values are used in this study) different values limited to the range from $0^{\circ}$ to $90^{\circ}$. Note that the $\alpha_{2}$ value is dependent on its orientation (when the collector or module is facing due south, west, east, and north, the value of $\alpha_{2}$ is equal to $0^{\circ}, 270^{\circ}, 90^{\circ}$, and $180^{\circ}$, respectively). In addition, note that the selection of values $\beta_{2}$ would be better if it had an equal increment value (the increment value used in this study is 0.2 ) and the selection should focus on the values that produce the highest total solar 
irradiance, $I_{t o t}$, to have a more accurate value of the optimum tilt angle, $\beta_{\text {opt }}$, of the solar PV module's surface.

- $\quad$ Phase 3

Calculate the solar geometric parameters, that is, the declination angle, $\delta$; apparent solar time, AST; equation of time, ET; hour angle, h; solar altitude angle, $\beta_{1}$; solar azimuth angle, $\alpha_{1}$; and collector angle, $\theta$. Note that the solar geometric parameters need to be computed for each of the values of the collector tilt angle, $\beta_{2}$. Hence, there will be 17 sets of data for the solar geometric parameters for each selected day (day-21st of each month). In addition, note that these data should be calculated for at most every one hour, for one whole day, or 24 hours (there are 48 data points in this study as the increment was taken to be $30 \mathrm{~min})$.

- $\quad$ Phase 4

Compute the direct normal irradiance, $I_{\mathrm{DN}}$; direct irradiance, $I_{\mathrm{D}}$; diffuse irradiance, $I_{\mathrm{S}}$; and reflected irradiance, $I_{\mathrm{R}}$. Next, compute the total solar irradiance, $I_{\text {tot }}$. Note that in this study, there are 17 sets of daily data for $I_{\text {tot }}$ of different collector tilt angles, $\beta_{2}$, which are totalled up daily in increments of 30 min starting from 12:00 AM to 11:30 PM.

- $\quad$ Phase 5

From the plotted graph of total solar irradiance, $I_{\text {tot }}$, versus military time, $\mathrm{h}$, the highest Itot could be seen. However, its respective collector tilt angle, $\beta_{2}$, should not be taken as the optimum tilt angle, $\beta_{\text {opt }}$, to avoid low data accuracy.

- $\quad$ Phase 6

Estimate the insolation, $H$, value by finding the area under the curve of the total solar irradiance, $I_{\text {tot, }}$ versus military time, $h$, graph. This area may be approximated by a numerical integration technique, that is, the trapezoidal rule. It involves dividing the area under the curve into thin trapezoidal-shaped areas and adding them together to obtain the total area, approximating the $H$ value. Next, plot another graph of insolation, $H$, versus collector tilt angle, $\beta_{2}$. Consequently, the accurate value of optimum tilt angle, $\beta_{\text {opt }}$, could be identified from this graph, as the trapezoidal method helps to avoid overcalculated values.

1. Time and solar angles: The declination angle, $\delta$, is the sun's angular displacement to the earth's equator (refer to Figure 6). For the northern hemisphere, $\delta$ is given in degrees by Equation (1) below [34,55-57]:

$$
\delta=23.45^{\circ} \sin \left[\frac{N+284}{365} \times 360^{\circ}\right]
$$

where $N$ is the day number of the year. The $23.45^{\circ}$ is known as the mean oblique ecliptic, and its sign is positive for the northern hemisphere and negative for the southern hemisphere. The $\delta$ varies between $23.5^{\circ}$ (northern summer solstice) to $-23.5^{\circ}$ (southern summer solstice). The Earth's surface is divided into a grid consisting of lines known as latitude, L, and longitude, Long. For Long, the origin $0^{\circ}$ is known as the prime meridian (the north-south line that passes through Greenwich, England), whereas for $\mathrm{L}$, the origin $0^{\circ}$ is the equator. To traverse one degree of Long, it would take up to four minutes by recognising that there are $24 \mathrm{~h} / \mathrm{day}, 60 \mathrm{~min} /$ hour, and $1440 \mathrm{~min} /$ day. The apparent solar time, AST, or local solar time for eastern longitudes, is given in minutes by Equation (2) below [56,57]:

$$
\mathrm{AST}=\mathrm{LST}-(4 \mathrm{~min} / \mathrm{deg})(\mathrm{LSTM}-\mathrm{Long})+\mathrm{ET}
$$

LST stands for local standard time (given in minutes), LSTM is local standard time meridian, Long is longitude, and ET is the equation of time. ET is a measure of the 
extent by which solar time runs faster or slower than an everyday running clock running at a uniform rate. It is given in minutes by Equation (3) below [56,57]:

$$
\mathrm{ET}=9.87 \sin (2 \mathrm{D})-7.53 \cos (\mathrm{D})-1.5 \sin (\mathrm{D})
$$

where,

$$
\mathrm{D}=\frac{(N-81)}{365} 360^{\circ}
$$

The hour angle, $h$, is the sun's angular position to the west or east of the local meridian. Before solar noon (solar noon means $h=0^{\circ}$ ), the sign of $h$ is negative (morning), whereas its sign is positive after solar noon (afternoon), and it is related to AST given in degrees by the Equation (5) below [56,57]:

$$
\mathrm{h}=\frac{\mathrm{AST}-720 \mathrm{~min}}{4 \mathrm{~min} / \mathrm{deg}}
$$

Figure 5 shows a fixed PV module lying flat or horizontally on the earth's surface. The solar altitude angle, $\beta_{1}$, is the sun's apparent angular position (if a person is standing in such a way that the person is directly facing the sun). After calculation, if $\beta_{1}$ is showing negative values, it means that the earth shades the sunlight; hence, there is no solar radiation at the given time, and the total solar radiation, $I_{\mathrm{tot}}$, is equal to zero. It is given in radian by Equation (6) below [55-57]:

$$
\sin \left(\beta_{1}\right)=\cos (\mathrm{L}) \cos (\delta) \cos (\mathrm{h})+\sin (\mathrm{L}) \sin (\delta)
$$

where L stands for latitude (sign is positive in either north or south hemisphere), $\delta$ is declination angle, and $\mathrm{h}$ is hour angle. On the other hand, the solar azimuth angle, $\alpha_{1}$, is the angular position of the sun viewed from the north-south line, which is given in radian by Equation (7) below [56,57]:

$$
\cos \left(\alpha_{1}\right)=\frac{\sin \left(\beta_{1}\right) \sin (L)-\sin (\delta)}{\cos \left(\beta_{1}\right) \cos (L)}
$$

Shown with a sign, the solar azimuth angle will be negative in the morning, and after solar noon, it will be positive. This is to follow the clockwise direction, and the sign of $\alpha_{1}$ matches that of the hour angle, $\mathrm{h}$.

2. Collector angles: In this study, the term collector is specified on the solar PV system, that is, the solar PV module. The collector tilt angle, $\beta_{2}$, and orientation define the position of a solar PV module. Figure 7 illustrates a fixed PV module facing southwest $\left(0^{\circ}<\alpha_{2}<90^{\circ}\right.$ and $\left.\beta_{2}>0^{\circ}\right)$. As seen in the figure above, $\beta_{2}$ measures the angle of the collector surface from the ground. The collector angle, $\theta$, is the angle between the sun and the normal to the collector surface. The collector angle is calculated in radian as shown by Equation (8) below [56,57]:

$$
\cos (\theta)=\sin \left(\beta_{1}\right) \cos \left(\beta_{2}\right)+\cos \left(\beta_{1}\right) \sin \left(\beta_{2}\right) \cos \left(\alpha_{1}-\alpha_{2}\right)
$$

where $\beta_{1}$ is the solar altitude angle, $\alpha_{1}$ is the solar azimuth angle, and $\alpha_{2}$ is the azimuth angle of the normal to the collector surface. After calculation, if the collector angle, $\theta$, is more than $90^{\circ}$, it means that the collector is installed in such a way that the collector shades itself.

3. Solar irradiance: Total solar irradiance, $I_{\text {tot }}$, is the total solar energy incident upon a surface. Figure 8 illustrates the components of solar irradiance. As seen, the direct irradiance, $I_{\mathrm{D}}$; diffuse irradiance or sky radiation, $I_{S}$; and reflected irradiance, $I_{R}$, are the three components of solar irradiance expressed in $\mathrm{W} / \mathrm{m}^{2}$ [34]. The sum of these 
three components will be the total solar irradiance, which is given by Equation (9) below (output value would be in $\mathrm{W} / \mathrm{m}^{2}$ ) [56,57]:

$$
I_{\text {tot }}=I_{\mathrm{D}}+I_{\mathrm{S}}+I_{\mathrm{R}}
$$

The direct irradiance, $I_{\mathrm{D}}$, is calculated by Equation (10), where the direct normal irradiance, $I_{\mathrm{DN}}\left(\mathrm{W} / \mathrm{m}^{2}\right)$, is found by using Equations (11) and (12); in addition, it is used to find the atmospheric pressure relative to a standard atmosphere, $p / p_{0}$ (unitless) [56-58]:

$$
\begin{gathered}
I_{\mathrm{D}}=I_{\mathrm{DN}} \cos (\theta) \\
I_{\mathrm{DN}}=A \exp \left(-\frac{p}{p_{o}}\left(\frac{B}{\sin \left(\beta_{1}\right)}\right)\right) \\
\frac{p}{p_{o}}=\exp (-0.1184 z)
\end{gathered}
$$

where $\theta$ is the collector angle, $A$ is the apparent solar irradiation or apparent extraterrestrial solar intensity, $B$ is the atmospheric extinction coefficient, and $z$ is the elevation (in kilometres above the sea level). The diffuse irradiance, $I_{S}$, is given by the following Equation (13) [56,57,59]:

$$
I_{\mathrm{S}}=C I_{\mathrm{DN}}\left[D I F_{\mathrm{LJ}}\right]
$$

where,

$$
D I F_{\mathrm{LJ}}=\frac{1+\cos \left(\beta_{2}\right)}{2}
$$

where DIF $F_{\mathrm{LJ}}$ is the Liu and Jordan's [59] ratio of the average daily diffuse radiation on a tilted surface to that on a horizontal surface, $\beta_{2}$ is the module or collector tilt angle, and $C$ is the ratio of diffuse radiation on a horizontal surface to direct normal irradiation. The reflected irradiance, $I_{R}$, is denoted in Equation (15) [56-58], where $\rho$ is the foreground reflectivity (Table 4 shows the typically used values of $\rho$ ). Note that the approximate total solar irradiance, $I_{\text {tot }}$, given by $\rho$ only applies to the clear sky condition, whereas in cases of cloudy or overcast sky, additional information is needed to reduce the quantity of irradiance accordingly.

$$
I_{\mathrm{R}}=I_{\mathrm{DN}} \rho\left(C+\sin \left(\beta_{1}\right)\right)\left[\frac{1-\cos \left(\beta_{2}\right)}{2}\right]
$$

The insolation, $H$, also known as solar irradiation or solar radiant exposure, is the incident solar energy per unit of surface area (unit is $\mathrm{J} / \mathrm{m}^{2}$ ). $H$ is found by integrating the $I_{\text {tot }}$ over a specific time. Hence,

$$
H=\int_{t_{1}}^{t_{2}} I_{\text {tot }} d t
$$

where the period is usually taken for one whole day. $H$ is also the daily total solar energy incident on a unit surface of a module or collector. Therefore, the daily total solar energy, $E_{\text {solar }}$, can be obtained if the insolation, $H$, is multiplied by the surface area of a collector, $A_{\text {collector }}\left(\mathrm{m}^{2}\right)$. It is given in joules by Equation (17) below (unit is J or Wh):

$$
E_{\text {solar }}=H A_{\text {collector }}
$$

4. Total solar photovoltaic power output: By using the theoretical formula, the total electrical energy generated, $E_{\text {elect }}$, by using the collector or total solar photovoltaic power output can be obtained by multiplying daily total solar energy, $E_{\text {solar, }}$ with the solar cell efficiency, $\eta_{\text {cell }}$, denoted in Equation (18) as follows (unit is J or Wh):

$$
E_{\text {elect }}=\eta_{\text {cell }} E_{\text {solar }}
$$


where the typical range of solar cell efficiency, $\eta_{\text {cell }}$, is approximately 0.15 to 0.25 (15\% to $25 \%$ ), and taken to be 0.20 (mean of the given range) in this study. To compute the yearly data set, the total number of days in a year is assumed to be 365 (does not assume leap year). Table 3 shows the data of the respective month, from January to December, assumed in this study.

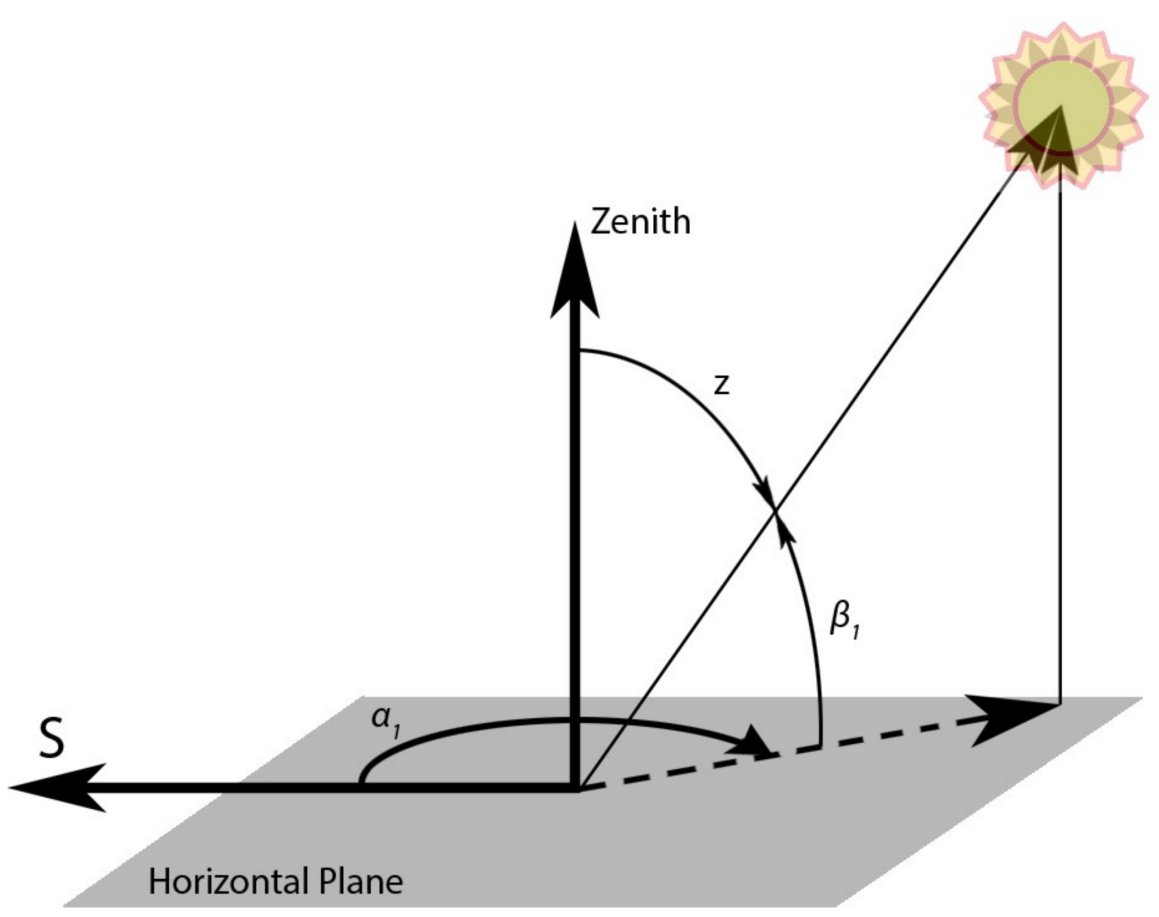

Figure 5. Solar azimuth, zenith angle, and solar altitude.

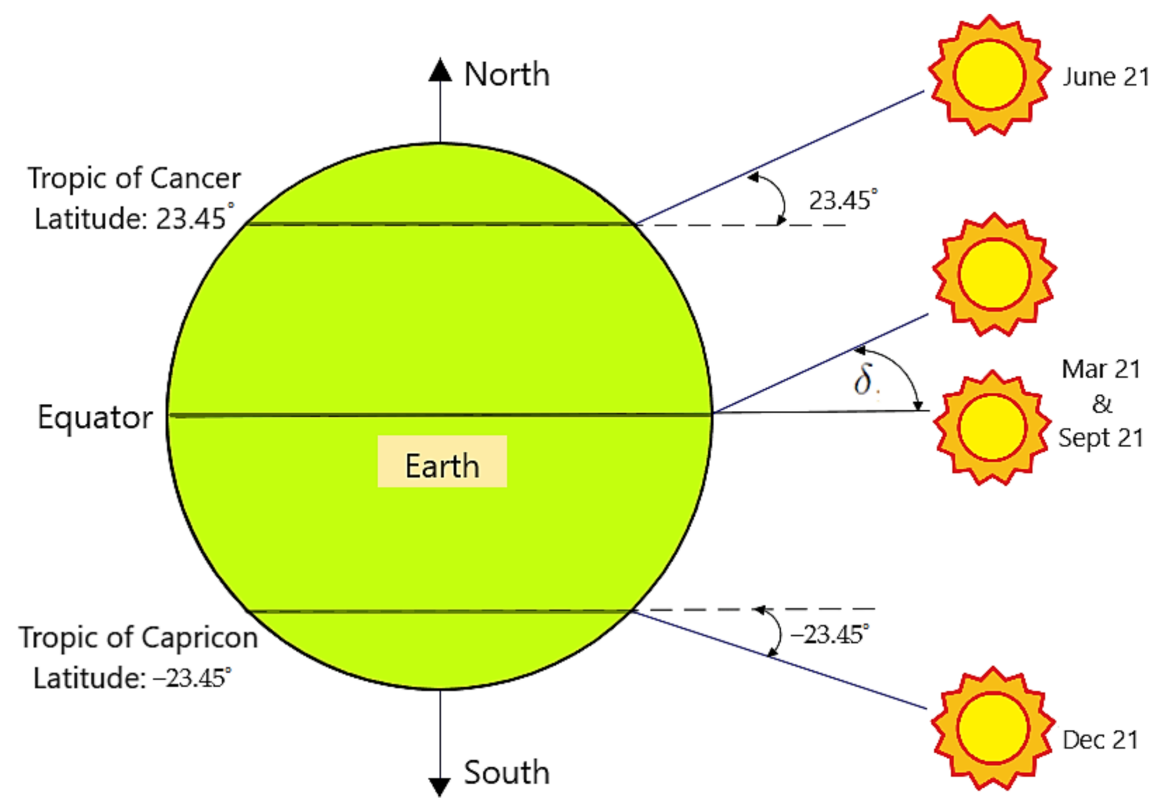

Figure 6. Solar declination angle illustration. 


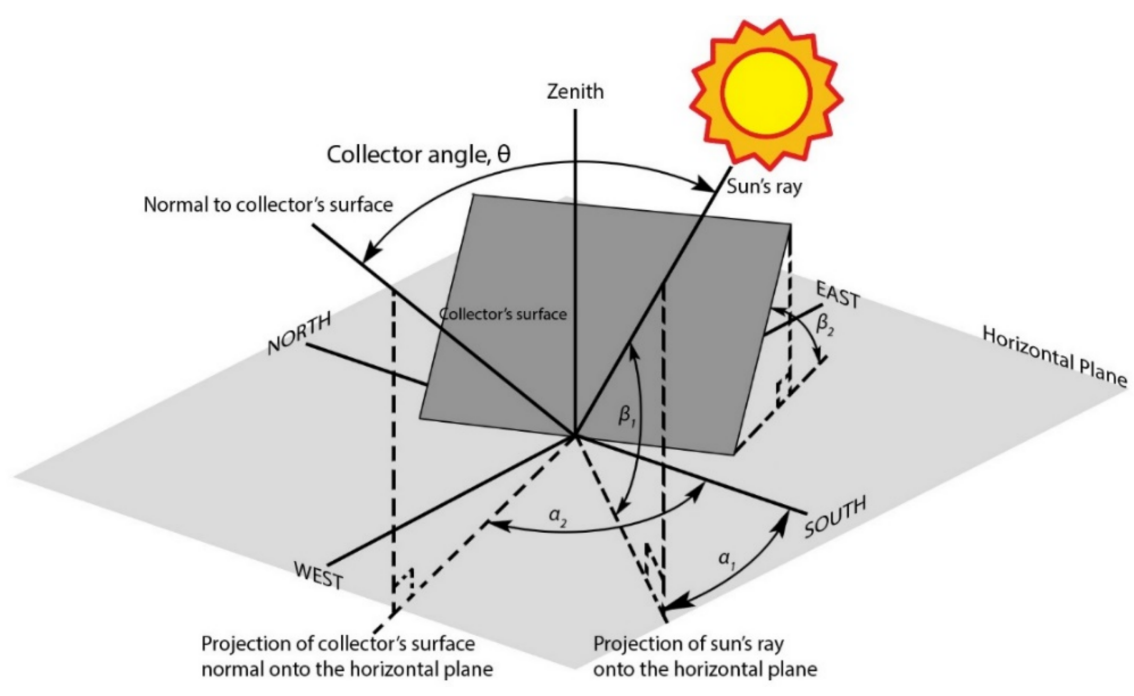

Figure 7. Solar and collector angles.

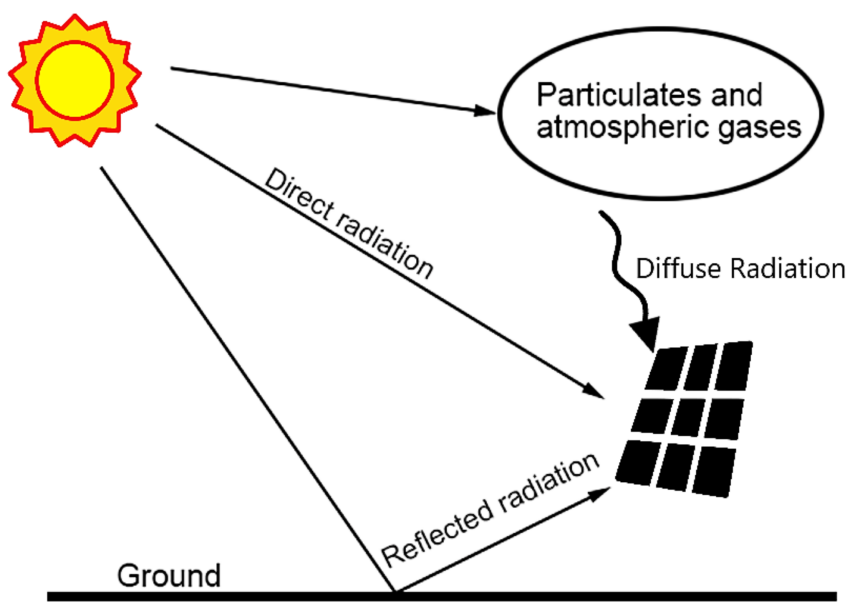

Figure 8. Components of solar irradiance: direct, diffuse, and reflected radiation.

Table 3. Month's data.

\begin{tabular}{ccc}
\hline Month & Day Number of Year, $N$ & Total Days \\
\hline January (Jan) & 21 & 31 \\
February (Feb) & 52 & 28 \\
March (Mar) & 80 & 31 \\
April (Apr) & 111 & 30 \\
May (May) & 141 & 31 \\
June (June) & 172 & 30 \\
July (Jul) & 202 & 31 \\
August (Aug) & 233 & 31 \\
September (Sept) & 264 & 30 \\
October (Oct) & 294 & 31 \\
November (Nov) & 325 & 30 \\
December (Dec) & 355 & 31 \\
January (Jan) & 21 & 31 \\
\hline
\end{tabular}


Table 4. Typical foreground reflectivity, $\rho$ values [60].

\begin{tabular}{cc}
\hline Type of Foreground & $\rho$ \\
\hline Corrugated roof & $0.10-0.15$ \\
Coloured paint & $0.15-0.35$ \\
Trees & $0.15-0.18$ \\
Asphalt & $0.05-0.20$ \\
Concrete & $0.25-0.70$ \\
Grass & $0.25-0.30$ \\
Ice & $0.30-0.50$ \\
\hline
\end{tabular}

\subsection{Isotropic Diffuse Sky Radiation Models}

There are four different isotropic diffuse sky radiation models used to compare the diffuse components of solar irradiance at EPLISSI: the models proposed by Liu and Jordan [59], Koronakis [61], Badescu [62], and Tian [63]. These isotropic models were selected as they are the most widely used models to estimate the total solar irradiance.

According to Koronakis [61], Liu and Jordan [59] was among the first to develop a relationship between the fraction of the monthly average daily solar diffuse component on the horizontal and the clearness index, while the Koronakis, Badescu, and Tian models were developed to increase the Liu and Jordan diffuse sky radiation model's accuracy. The ratio of the average daily diffuse radiation on a tilted surface to that on a horizontal surface for Liu and Jordan, Koronakis, Badescu, and Tian is denoted as $D I F_{\mathrm{LJ}}, D I F_{\mathrm{K}}, D I F_{\mathrm{B}}$, and $D I F_{\mathrm{T}}$, respectively. They are given as follows:

Liu and Jordan [59] model

$$
D I F_{\mathrm{LJ}}=\frac{1+\cos \left(\beta_{2}\right)}{2}
$$

Koronakis [61] model

$$
D I F_{\mathrm{K}}=\frac{2+\cos \left(\beta_{2}\right)}{3}
$$

Badescu [62] model

$$
D I F_{\mathrm{B}}=\frac{3+\cos \left(2 \beta_{2}\right)}{4}
$$

Tian [63] model

$$
D I F_{\mathrm{T}}=1-\frac{\cos \left(\beta_{2}\right)}{180}
$$

This section aims to compare the results of PV power output in the four isotropic models with the GSA 2.3 results to find the most accurate and suitable model to be used in EPLISSI. However, the total solar irradiance results are needed to obtain the respective model's PV power output. As there are three components of solar irradiance, obtaining the direct irradiance and reflected irradiance is kept the same: using all the equations in Section 2.3, excluding Equation (14). Therefore, the diffuse component will be compared. In other words, the only difference in obtaining the total solar irradiance using those four models are by substituting Equations (19)-(21) and Equation (22) into Equation (14), following the method used by [35].

\section{Results and Discussions}

There are four subsections in this results and discussions section. In Section 3.1, the PV power output results calculated using the four isotropic sky radiation models are compared to the simulated GSA 2.3 results. Furthermore, the optimum tilt angle obtained by using each method will also be provided and discussed. On the other hand, the last three subsections show the tilt angle and orientation analysis concerning its configuration through the Liu and Jordan model. Their respective configurations for each of the sections are listed in Table 5. 
Table 5. Various configurations used in each section.

\begin{tabular}{ccc}
\hline Section & Orientation & Variation of Tilt Angle, $\boldsymbol{\beta}_{2}$ \\
\hline Section 3.2 & $\alpha_{2}=0^{\circ}$ & $0^{\circ}$ \\
& & $6.25^{\circ}$ \\
& $\alpha_{2}=0^{\circ}$ & $\beta_{\text {opt }}$ \\
Section 3.3 & $\alpha_{2}=0^{\circ}$ and $180^{\circ}$ & $\beta_{\text {opt }}$ \\
& $\alpha_{2}=0^{\circ}$ & $\beta_{\text {opt }}$ \\
Section 3.4 & $\alpha_{2}=180^{\circ}$ & $8.05^{\circ}$ \\
& & $0^{\circ}$ \\
\hline
\end{tabular}

\subsection{Photovoltaic Power Output}

There are four isotropic sky radiation models analysed in this section, that is, the Liu and Jordan, Koronakis, Badescu, and Tian models. Firstly, the optimum tilt angle, $\beta$ opt, corresponding to its respective method will be discussed. Next, the PV power output results of four isotropic sky radiation models will be compared to the PV power output result provided by GSA 2.3 by considering the same installed capacity of $2.5 \mathrm{kWp}$. In addition, there are three cases of monthly variations of collector tilt angle, $\beta_{2}$, that are calculated or simulated using all five methods, that is, $\beta_{2}=6^{\circ}, \beta_{2}=7^{\circ}$, and $\beta_{2}=8^{\circ}$, while the orientation used by all methods will be fixed facing due south $\left(\alpha_{2}=0^{\circ}\right)$.

Based on Table 6, the optimum tilt angle, $\beta$ opt, provided by GSA 2.3 and calculated using the Liu and Jordan model, Koronakis model, Badescu model, and Tian model are $6^{\circ}, 8^{\circ}, 8^{\circ}, 8^{\circ}$, and $7^{\circ}$, respectively. As the optimum tilt angle is derived from the total insolation (not the total PV power output) provided by each of the isotropic models, they show a close agreement with the data provided by GSA 2.3. On the other hand, although the differences of optimum tilt angle between all the isotropic models and GSA 2.3 are insignificant, the contradiction between these data might occur due to utilising the semiempirical data supported by satellites and meteorological data in GSA 2.3. In contrast, the isotropic diffuse sky radiation model is based purely on the sun angle's mathematical model [53]. Since the Tian model provides an optimum tilt angle close to the GSA 2.3 result, it is more preferred.

Table 6. The optimum tilt angle, $\beta$ opt, corresponding to its respective method oriented facing due south.

\begin{tabular}{cc}
\hline Type of Model & Optimum Tilt Angle, $\beta$ opt \\
\hline GSA 2.3 & $6^{\circ}$ \\
Liu and Jordan & $8^{\circ}$ \\
Koronakis & $8^{\circ}$ \\
Badescu & $8^{\circ}$ \\
Tian & $7^{\circ}$ \\
\hline
\end{tabular}

The GSA 2.3 result of PV power output data shown in Figure 9 illustrates that meaningful solar energy can be harvested as early as 8 AM and as late as at 4 PM, with peak solar output between 10 AM to 2 PM for all three variations of the collector tilt angle. Meanwhile, the average daily PV power output generated by the $2.5 \mathrm{kWp}$ system for the collector positioned at $\beta_{2}=6^{\circ}, \beta_{2}=7^{\circ}$, and $\beta_{2}=8^{\circ}$ are $8.77 \mathrm{kWh} / \mathrm{m}^{2}, 8.76 \mathrm{kWh} / \mathrm{m}^{2}$, and $8.75 \mathrm{kWh} / \mathrm{m}^{2}$, respectively. The differences between these quantities are insignificant; however, the outcome suggests that solar PV potential is high; hence, this further indicates the possibilities of a solar PV system to be delivered at EPLISSI. 


\begin{tabular}{|c|c|c|c|c|c|c|c|c|c|c|c|c|}
\hline Hour & Jan & Feb & Mar & Apr & May & Jun & Jul & Aug & Sep & Oct & Nov & Dec \\
\hline $\mathbf{0 - 1}$ & 0 & 0 & 0 & 0 & 0 & 0 & 0 & 0 & 0 & 0 & 0 & 0 \\
\hline $\mathbf{1 - 2}$ & 0 & 0 & 0 & 0 & 0 & 0 & 0 & 0 & 0 & 0 & 0 & 0 \\
\hline $\mathbf{2 - 3}$ & 0 & 0 & 0 & 0 & 0 & 0 & 0 & 0 & 0 & 0 & 0 & 0 \\
\hline $\mathbf{3 - 4}$ & 0 & 0 & 0 & 0 & 0 & 0 & 0 & 0 & 0 & 0 & 0 & 0 \\
\hline $\mathbf{4 - 5}$ & 0 & 0 & 0 & 0 & 0 & 0 & 0 & 0 & 0 & 0 & 0 & 0 \\
\hline $\mathbf{5 - 6}$ & 0 & 0 & 0 & 0 & 0 & 0 & 0 & 0 & 0 & 0 & 0 & 0 \\
\hline $\mathbf{6 - 7}$ & 8 & 8 & 23 & 58 & 75 & 62 & 45 & 46 & 65 & 87 & 81 & 28 \\
\hline $\mathbf{7 - 8}$ & 244 & 277 & 341 & 423 & 416 & 357 & 317 & 342 & 379 & 431 & 440 & 342 \\
\hline $\mathbf{8 - 9}$ & 599 & 691 & 788 & 876 & 831 & 703 & 656 & 732 & 754 & 803 & 827 & 731 \\
\hline $\mathbf{9 - 1 0}$ & 908 & 1045 & 1170 & 1228 & 1161 & 998 & 960 & 1084 & 1066 & 1121 & 1130 & 1050 \\
\hline $\mathbf{1 0 - 1 1}$ & 1112 & 1285 & 1386 & 1412 & 1311 & 1185 & 1166 & 1288 & 1255 & 1294 & 1241 & 1228 \\
\hline $\mathbf{1 1 - 1 2}$ & 1160 & 1325 & 1401 & 1390 & 1301 & 1225 & 1228 & 1325 & 1295 & 1279 & 1197 & 1245 \\
\hline $\mathbf{1 2 - 1 3}$ & 1107 & 1243 & 1290 & 1221 & 1136 & 1139 & 1163 & 1236 & 1191 & 1140 & 1014 & 1116 \\
\hline $\mathbf{1 3 - 1 4}$ & 927 & 1111 & 1135 & 1104 & 935 & 971 & 1014 & 1114 & 1036 & 942 & 802 & 912 \\
\hline $\mathbf{1 4 - 1 5}$ & 740 & 924 & 958 & 891 & 734 & 808 & 837 & 893 & 835 & 725 & 625 & 721 \\
\hline $\mathbf{1 5 - 1 6}$ & 553 & 709 & 742 & 658 & 498 & 588 & 595 & 621 & 571 & 501 & 437 & 502 \\
\hline $\mathbf{1 6 - 1 7}$ & 328 & 446 & 453 & 384 & 285 & 325 & 328 & 338 & 293 & 253 & 234 & 284 \\
\hline $\mathbf{1 7 - 1 8}$ & 104 & 172 & 164 & 139 & 101 & 115 & 127 & 122 & 82 & 54 & 48 & 71 \\
\hline $\mathbf{1 8 - 1 9}$ & 0 & 5 & 5 & 1 & 1 & 4 & 6 & 3 & 0 & 0 & 0 & 0 \\
\hline $\mathbf{1 9 - 2 0}$ & 0 & 0 & 0 & 0 & 0 & 0 & 0 & 0 & 0 & 0 & 0 & 0 \\
\hline $\mathbf{2 0 - 2 1}$ & 0 & 0 & 0 & 0 & 0 & 0 & 0 & 0 & 0 & 0 & 0 & 0 \\
\hline $\mathbf{2 1 - 2 2}$ & 0 & 0 & 0 & 0 & 0 & 0 & 0 & 0 & 0 & 0 & 0 & 0 \\
\hline $\mathbf{2 2 - 2 3}$ & 0 & 0 & 0 & 0 & 0 & 0 & 0 & 0 & 0 & 0 & 0 & 0 \\
\hline $\mathbf{2 3 - 2 4}$ & 0 & 0 & 0 & 0 & 0 & 0 & 0 & 0 & 0 & 0 & 0 & 0 \\
\hline Sum & $\mathbf{7 7 9 0}$ & $\mathbf{9 2 4 1}$ & $\mathbf{9 8 5 6}$ & $\mathbf{9 7 8 5}$ & $\mathbf{8 7 8 5}$ & $\mathbf{8 4 8 0}$ & $\mathbf{8 4 4 2}$ & $\mathbf{9 1 4 4}$ & $\mathbf{8 8 2 2}$ & $\mathbf{8 6 3 0}$ & $\mathbf{8 0 7 6}$ & $\mathbf{8 2 3 0}$ \\
\hline
\end{tabular}

(a)

\begin{tabular}{|c|c|c|c|c|c|c|c|c|c|c|c|c|}
\hline Hour & Jan & Feb & Mar & Apr & May & Jun & Jul & Aug & Sep & Oct & Nov & Dec \\
\hline $\mathbf{0 - 1}$ & 0 & 0 & 0 & 0 & 0 & 0 & 0 & 0 & 0 & 0 & 0 & 0 \\
\hline $\mathbf{1 - 2}$ & 0 & 0 & 0 & 0 & 0 & 0 & 0 & 0 & 0 & 0 & 0 & 0 \\
\hline $\mathbf{2 - 3}$ & 0 & 0 & 0 & 0 & 0 & 0 & 0 & 0 & 0 & 0 & 0 & 0 \\
\hline $\mathbf{3 - 4}$ & 0 & 0 & 0 & 0 & 0 & 0 & 0 & 0 & 0 & 0 & 0 & 0 \\
\hline $\mathbf{4 - 5}$ & 0 & 0 & 0 & 0 & 0 & 0 & 0 & 0 & 0 & 0 & 0 & 0 \\
\hline $\mathbf{5 - 6}$ & 0 & 0 & 0 & 0 & 0 & 0 & 0 & 0 & 0 & 0 & 0 & 0 \\
\hline $\mathbf{6 - 7}$ & 7 & 8 & 23 & 58 & 73 & 61 & 45 & 45 & 65 & 88 & 82 & 29 \\
\hline $\mathbf{7 - 8}$ & 248 & 280 & 341 & 420 & 410 & 351 & 312 & 339 & 378 & 433 & 444 & 347 \\
\hline $\mathbf{8 - 9}$ & 604 & 695 & 788 & 872 & 824 & 696 & 650 & 728 & 753 & 805 & 833 & 738 \\
\hline $\mathbf{9 - 1 0}$ & 914 & 1049 & 1170 & 1224 & 1154 & 990 & 954 & 1079 & 1065 & 1123 & 1135 & 1057 \\
\hline $\mathbf{1 0 - 1 1}$ & 1118 & 1289 & 1386 & 1408 & 1304 & 1178 & 1160 & 1284 & 1254 & 1297 & 1246 & 1235 \\
\hline $\mathbf{1 1 - 1 2}$ & 1165 & 1329 & 1401 & 1386 & 1295 & 1218 & 1221 & 1320 & 1294 & 1281 & 1201 & 1251 \\
\hline $\mathbf{1 2 - 1 3}$ & 1111 & 1246 & 1290 & 1219 & 1131 & 1133 & 1157 & 1232 & 1190 & 1142 & 1017 & 1120 \\
\hline $\mathbf{1 3 - 1 4}$ & 930 & 1114 & 1135 & 1102 & 931 & 966 & 1008 & 1110 & 1035 & 943 & 804 & 916 \\
\hline $\mathbf{1 4 - 1 5}$ & 743 & 926 & 958 & 889 & 731 & 804 & 832 & 890 & 833 & 725 & 626 & 724 \\
\hline $\mathbf{1 5 - 1 6}$ & 555 & 711 & 742 & 656 & 495 & 584 & 591 & 619 & 570 & 502 & 438 & 504 \\
\hline $\mathbf{1 6 - 1 7}$ & 330 & 448 & 453 & 383 & 283 & 322 & 326 & 336 & 292 & 253 & 236 & $\mathbf{2 8 6}$ \\
\hline $\mathbf{1 7 - 1 8}$ & 106 & 173 & 164 & 138 & 99 & 113 & 125 & 121 & 81 & 54 & 49 & 73 \\
\hline $\mathbf{1 8 - 1 9}$ & 0 & 5 & 5 & 1 & 1 & 4 & 6 & 3 & 0 & 0 & 0 & 0 \\
\hline $\mathbf{1 9 - 2 0}$ & 0 & 0 & 0 & 0 & 0 & 0 & 0 & 0 & 0 & 0 & 0 & 0 \\
\hline $\mathbf{2 0 - 2 1}$ & 0 & 0 & 0 & 0 & 0 & 0 & 0 & 0 & 0 & 0 & 0 & 0 \\
\hline $\mathbf{2 1 - 2 2}$ & 0 & 0 & 0 & 0 & 0 & 0 & 0 & 0 & 0 & 0 & 0 & 0 \\
\hline $\mathbf{2 2 - 2 3}$ & 0 & 0 & 0 & 0 & 0 & 0 & 0 & 0 & 0 & 0 & 0 & 0 \\
\hline $\mathbf{2 3 - 2 4}$ & 0 & 0 & 0 & 0 & 0 & 0 & 0 & 0 & 0 & 0 & 0 & 0 \\
\hline Sum & $\mathbf{7 8 3 1}$ & $\mathbf{9 2 7 3}$ & $\mathbf{9 8 5 6}$ & $\mathbf{9 7 5 6}$ & $\mathbf{8 7 3 1}$ & $\mathbf{8 4 2 0}$ & $\mathbf{8 3 8 7}$ & $\mathbf{9 1 0 6}$ & $\mathbf{8 8 1 0}$ & $\mathbf{8 6 4 6}$ & $\mathbf{8 1 1 1}$ & $\mathbf{8 2 8 0}$ \\
\hline
\end{tabular}

(b)

Figure 9. Cont. 


\begin{tabular}{|c|c|c|c|c|c|c|c|c|c|c|c|c|}
\hline Hour & Jan & Feb & Mar & Apr & May & Jun & Jul & Aug & Sep & Oct & Nov & Dec \\
\hline $\mathbf{0 - 1}$ & 0 & 0 & 0 & 0 & 0 & 0 & 0 & 0 & 0 & 0 & 0 & 0 \\
\hline $\mathbf{1 - 2}$ & 0 & 0 & 0 & 0 & 0 & 0 & 0 & 0 & 0 & 0 & 0 & 0 \\
\hline $\mathbf{2 - 3}$ & 0 & 0 & 0 & 0 & 0 & 0 & 0 & 0 & 0 & 0 & 0 & 0 \\
\hline $\mathbf{3 - 4}$ & 0 & 0 & 0 & 0 & 0 & 0 & 0 & 0 & 0 & 0 & 0 & 0 \\
\hline $\mathbf{4 - 5}$ & 0 & 0 & 0 & 0 & 0 & 0 & 0 & 0 & 0 & 0 & 0 & 0 \\
\hline $\mathbf{5 - 6}$ & 0 & 0 & 0 & 0 & 0 & 0 & 0 & 0 & 0 & 0 & 0 & 0 \\
\hline $\mathbf{6 - 7}$ & 7 & 8 & 23 & 57 & 71 & 59 & 43 & 45 & 64 & 89 & 84 & 30 \\
\hline $\mathbf{7 - 8}$ & 251 & 283 & 342 & 417 & 404 & 345 & 307 & 335 & 377 & 435 & 449 & 352 \\
\hline $\mathbf{8 - 9}$ & 609 & 698 & 788 & 868 & 816 & 689 & 644 & 723 & 752 & 807 & 838 & 744 \\
\hline $\mathbf{9 - 1 0}$ & 919 & 1053 & 1170 & 1220 & 1146 & 982 & 947 & 1074 & 1063 & 1125 & 1141 & 1064 \\
\hline $\mathbf{1 0 - 1 1}$ & 1123 & 1293 & 1386 & 1404 & 1297 & 1170 & 1153 & 1279 & 1252 & 1299 & 1251 & 1242 \\
\hline $\mathbf{1 1 - 1 2}$ & 1170 & 1332 & 1401 & 1383 & 1289 & 1211 & 1215 & 1316 & 1292 & 1282 & 1205 & 1257 \\
\hline $\mathbf{1 2 - 1 3}$ & 1115 & 1248 & 1290 & 1216 & 1126 & 1126 & 1151 & 1228 & 1188 & 1143 & 1020 & 1125 \\
\hline $\mathbf{1 3 - 1 4}$ & 933 & 1116 & 1135 & 1099 & 926 & 960 & 1003 & 1106 & 1034 & 944 & 806 & 919 \\
\hline $\mathbf{1 4 - 1 5}$ & 745 & 928 & 958 & 886 & 727 & 799 & 828 & 886 & 832 & 726 & 628 & 726 \\
\hline $\mathbf{1 5 - 1 6}$ & 557 & 713 & 742 & 654 & 492 & 579 & 587 & 616 & 569 & 502 & 440 & 507 \\
\hline $\mathbf{1 6 - 1 7}$ & 332 & 449 & 452 & 381 & 280 & 319 & 323 & 334 & 292 & 254 & 238 & 288 \\
\hline $\mathbf{1 7 - 1 8}$ & 107 & 174 & 164 & 137 & 98 & 111 & 123 & 120 & 81 & 54 & 50 & 74 \\
\hline $\mathbf{1 8 - 1 9}$ & 0 & 5 & 5 & 1 & 1 & 4 & 6 & 3 & 0 & 0 & 0 & 0 \\
\hline $\mathbf{1 9 - 2 0}$ & 0 & 0 & 0 & 0 & 0 & 0 & 0 & 0 & 0 & 0 & 0 & 0 \\
\hline $\mathbf{2 0 - 2 1}$ & 0 & 0 & 0 & 0 & 0 & 0 & 0 & 0 & 0 & 0 & 0 & 0 \\
\hline $\mathbf{2 1 - 2 2}$ & 0 & 0 & 0 & 0 & 0 & 0 & 0 & 0 & 0 & 0 & 0 & 0 \\
\hline $\mathbf{2 2 - 2 3}$ & 0 & 0 & 0 & 0 & 0 & 0 & 0 & 0 & 0 & 0 & 0 & 0 \\
\hline $\mathbf{2 3 - 2 4}$ & 0 & 0 & 0 & 0 & 0 & 0 & 0 & 0 & 0 & 0 & 0 & 0 \\
\hline $\mathbf{S u m}$ & $\mathbf{7 8 6 8}$ & $\mathbf{9 3 0 0}$ & $\mathbf{9 8 5 6}$ & $\mathbf{9 7 2 3}$ & $\mathbf{8 6 7 3}$ & $\mathbf{8 3 5 4}$ & $\mathbf{8 3 3 0}$ & $\mathbf{9 0 6 5}$ & $\mathbf{8 7 9 6}$ & $\mathbf{8 6 6 0}$ & $\mathbf{8 1 5 0}$ & $\mathbf{8 3 2 8}$ \\
\hline
\end{tabular}

(c)

Figure 9. GSA 2.3 data of average hourly profiles of total PV power output (Wh) of collector tilt angle (a) $\beta_{2}=6^{\circ},(\mathbf{b}) \beta_{2}=7^{\circ}$, and (c) $\beta_{2}=8^{\circ}$.

As illustrated in Figure 10, the theoretical results of the PV power output of all four isotropic models are overestimated compared to the data provided by GSA 2.3. The percentage difference of PV power output between each of the isotropic models and GSA 2.3 are all exceeding $30 \%$ (in the range of $31 \%$ to $32 \%$ ), for all variations of collector tilt angle $\left(\beta_{2}=6^{\circ}, \beta_{2}=7^{\circ}\right.$, and $\left.\beta_{2}=8^{\circ}\right)$. The computational method of GSA 2.3 PV power output data is based on provided technical weather data. Furthermore, GSA 2.3 assumed more losses affecting the PV performance, which can be divided into two main groups. These are the static losses (module surface pollution, the mismatch between PV modules, and losses in cables) and dynamic losses (depend on the irradiance/temperature conditions, which could change over the day and the seasons) [54]. However, the only efficiency taken into consideration using the isotropic models' calculation is the solar cell efficiency, $\eta_{\text {cell }}$, as can be seen in Equation (18) from Section 2.2. Hence, the difference of approximately $31 \%$ is deemed acceptable for these reasons, and any calculations using these models should take this into account.

On the other hand, the differences in the amount of PV power output between the Liu and Jordan, Koronakis, Badescu, and Tian models do not show a significant gap. However, among the isotropic models, the result suggests that the Tian model is the most accurate model for total solar irradiance and PV power output calculation at all variations of the tilt angle $\left(\beta_{2}=6^{\circ}, \beta_{2}=7^{\circ}\right.$, and $\left.\beta_{2}=8^{\circ}\right)$. Overall, the Tian model is preferred for approximating insolation. It has been proven to have the lowest difference among all models and the closest tilt angle agreement with GSA 2.3 data in EPLISSI. 


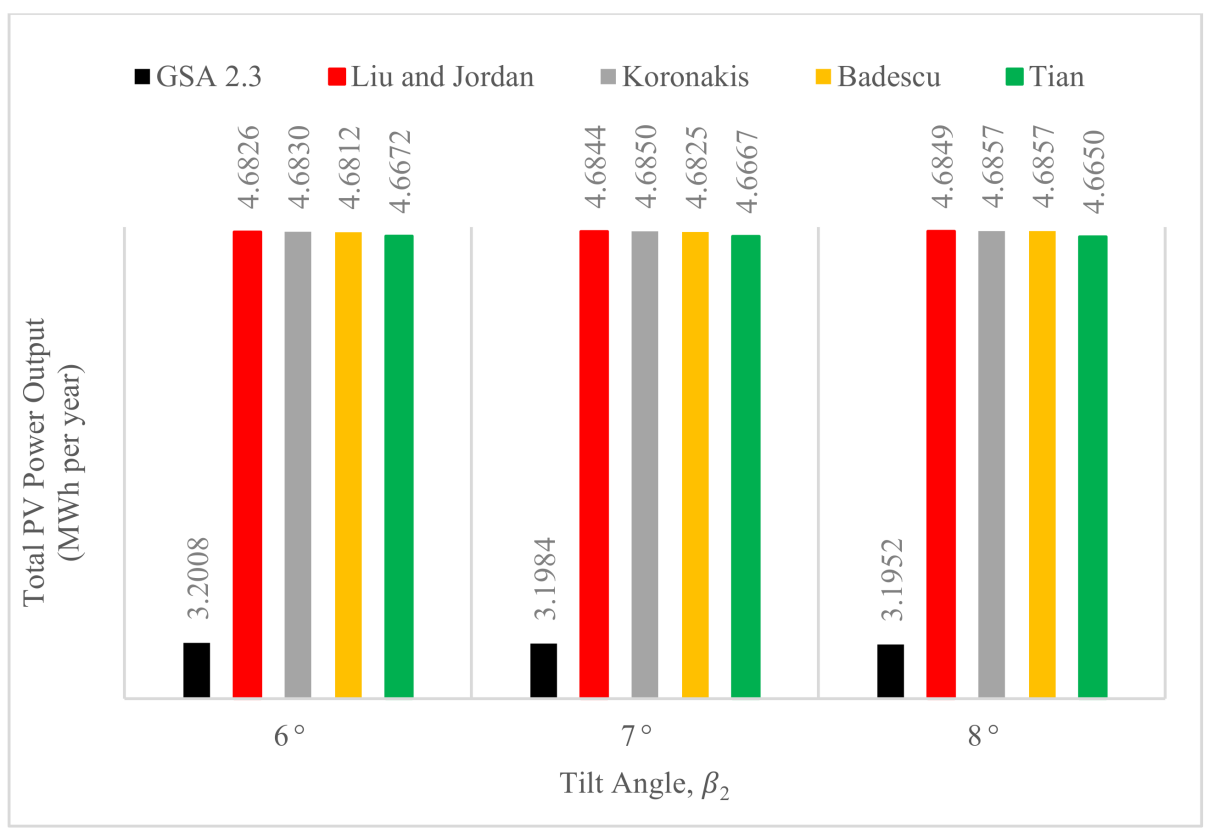

Figure 10. Result of total PV power output of the isotropic models and GSA 2.3.

3.2. Collector Positioned at Variation of Tilt Angle with Fixed Orientation of Facing Due South

Table 7 shows the variation of monthly tilt angle, while Figure 11 illustrates the tilt angle over one year or 365 days, with orientation facing due south of $\alpha_{2}=0^{\circ}$.

Table 7. Monthly variation tilt angle $\left(\alpha_{2}=0^{\circ}\right)$.

\begin{tabular}{cccc}
\hline Month & $\beta_{\mathbf{2}}=\mathbf{0}^{\circ}$ & $\beta_{\mathbf{2}}=\mathbf{6 . 2 5 ^ { \circ }}$ & $\boldsymbol{\beta}_{\mathbf{\text { opt }}}\left(\boldsymbol{\alpha}_{\mathbf{2}}=\mathbf{0}^{\circ}\right)$ \\
\hline 1 or Jan $(N=21)$ & $0^{\circ}$ & $6.25^{\circ}$ & $33.63^{\circ}$ \\
2 or Feb $(N=52)$ & $0^{\circ}$ & $6.25^{\circ}$ & $21.39^{\circ}$ \\
3 or Mar $(N=80)$ & $0^{\circ}$ & $6.25^{\circ}$ & $7.23^{\circ}$ \\
4 or Apr $(N=111)$ & $0^{\circ}$ & $6.25^{\circ}$ & $0^{\circ}$ \\
5 or May $(N=141)$ & $0^{\circ}$ & $6.25^{\circ}$ & $0^{\circ}$ \\
6 or June $(N=172)$ & $0^{\circ}$ & $6.25^{\circ}$ & $0^{\circ}$ \\
7 or Jul $(N=202)$ & $0^{\circ}$ & $6.25^{\circ}$ & $0^{\circ}$ \\
8 or Aug $(N=233)$ & $0^{\circ}$ & $6.25^{\circ}$ & $0^{\circ}$ \\
9 or Sept $(N=264)$ & $0^{\circ}$ & $6.25^{\circ}$ & $6.87^{\circ}$ \\
10 or Oct $(N=294)$ & $0^{\circ}$ & $6.25^{\circ}$ & $22.49^{\circ}$ \\
11 or $\operatorname{Nov}(N=325)$ & $0^{\circ}$ & $6.25^{\circ}$ & $33.55^{\circ}$ \\
12 or Dec $(N=355)$ & $0^{\circ}$ & $6.25^{\circ}$ & $37.39^{\circ}$ \\
\hline
\end{tabular}

As mentioned previously, there is a direct relationship between the PV module's position in terms of its tilt angle and orientation and the amount of solar energy captured. In this particular section, there are three different cases of variation of monthly tilt angle, $\beta_{2}$, which are $\beta_{2}=0^{\circ}$ (keep fixed in horizontal position), $\beta_{2}=6.25^{\circ}$ (keep fixed in tilted position with respect to the latitude), and $\beta_{2}=\beta_{\text {opt }}$ (optimum tilt angle). The apparent movement of the sun causes the monthly change in tilt angle for the case of $\beta_{\text {opt }}$. Table 8 shows the monthly insolation for $\beta_{2}=0^{\circ}, \beta_{2}=6.25^{\circ}$, and $\beta_{2}=\beta_{\text {opt }}$, as well as the yearly insolation. As shown, the collector tilted at $\beta_{\text {opt }}$ contributes the most considerable amount of insolation, $H$, recorded for every month, excluding April to August, where $\beta_{\text {opt }}=\beta_{2}$. 


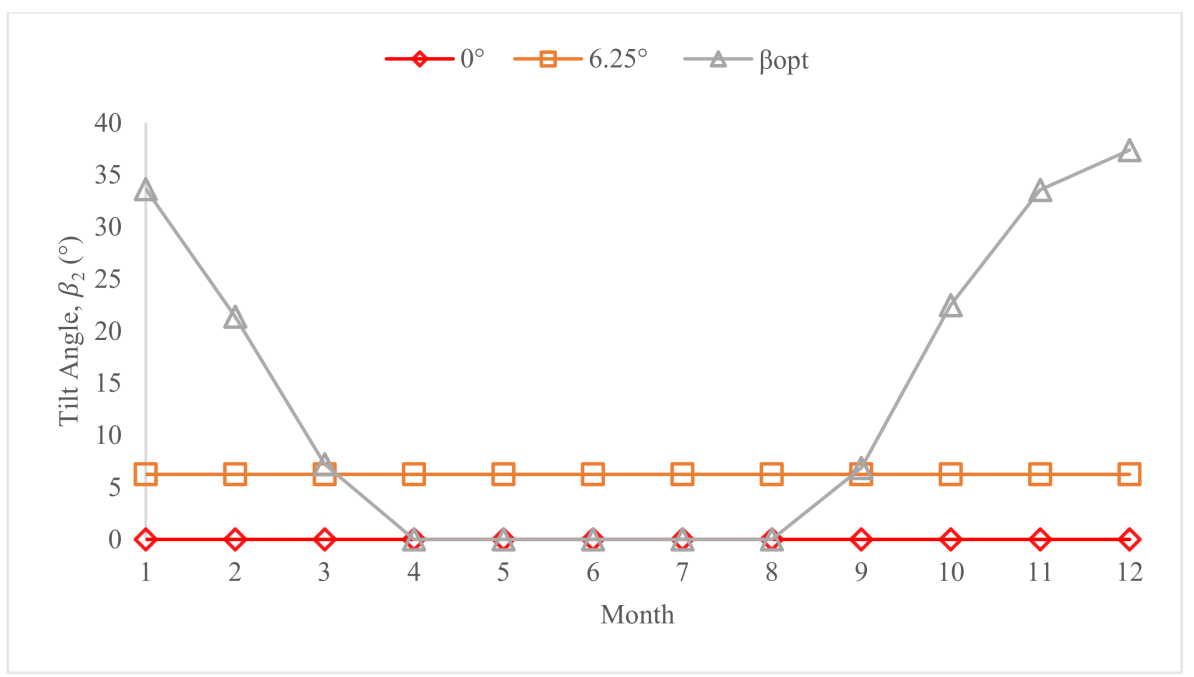

Figure 11. Monthly variation tilt angle $\left(\alpha_{2}=0^{\circ}\right)$.

Table 8. Insolation, $H\left(\mathrm{kWh} / \mathrm{m}^{2}\right.$ per day), with respect to the tilt angle.

\begin{tabular}{|c|c|c|c|}
\hline \multirow{2}{*}{ Month } & \multicolumn{3}{|c|}{ Insolation, $H\left(\mathrm{kWh} / \mathrm{m}^{2}\right.$ Per Month) } \\
\hline & $\beta_{2}=0^{\circ}$ & $\beta_{2}=6.25^{\circ}$ & $\beta_{\mathrm{opt}}\left(\alpha_{2}=0^{\circ}\right)$ \\
\hline 1 or $\operatorname{Jan}(N=21)$ & 215.14 & 227.44 & 252.3504 \\
\hline 2 or Feb $(N=52)$ & 208.24 & 215.17 & 222.6841 \\
\hline 3 or $\operatorname{Mar}(N=80)$ & 235.84 & 237.43 & 237.4567 \\
\hline 4 or $\operatorname{Apr}(N=111)$ & 219.25 & 214.88 & 219.2480 \\
\hline 5 or May $(N=141)$ & 216.38 & 208.19 & 216.3801 \\
\hline 6 or June $(N=172)$ & 204.84 & 195.69 & 204.8364 \\
\hline 7 or Jul $(N=202)$ & 214.89 & 206.71 & 214.8856 \\
\hline 8 or Aug $(N=233)$ & 221.77 & 217.39 & 221.7708 \\
\hline 9 or Sept $(N=264)$ & 217.92 & 219.24 & 219.2497 \\
\hline 10 or Oct $(N=294)$ & 218.05 & 225.34 & 233.3893 \\
\hline 11 or $\operatorname{Nov}(N=325)$ & 200.75 & 212.16 & 235.1755 \\
\hline 12 or $\operatorname{Dec}(N=355)$ & 205.32 & 218.96 & 250.9803 \\
\hline $\begin{array}{l}\text { Total insolation, } H \\
\left(\mathrm{kWh} / \mathrm{m}^{2} \text { per year) }\right.\end{array}$ & 2578.36 & 2598.60 & 2728.41 \\
\hline
\end{tabular}

Furthermore, based on Table 8, Figure 12 illustrates that when the collector is positioned at $\beta_{2}=6.25^{\circ}$, it provides slightly higher insolation values in January, February, March, September, October, November, and December, but suffers a drop starting from April to August as compared to when the collector is kept at $\beta_{2}=0^{\circ}$. The gain of insolation when the collector is positioned at $\beta_{\text {opt }}$ is approximately $20.24 \mathrm{kWh} / \mathrm{m}^{2}$ per year or $5.82 \%$, respectively, as compared to when the collector is positioned at $\beta_{2}=0^{\circ}$. Even though it is easier to install the collector in the horizontal position, it will reduce insolation, as the loss is considered high in the long run. On the contrary, the loss of insolation when the collector is positioned at $\beta_{2}=6.25^{\circ}$ as compared to when the collector is positioned at $\beta_{\text {opt }}$ is about $129.80 \mathrm{kWh} / \mathrm{m}^{2}$ per year or $4.99 \%$. By positioning the collector at an optimum tilt angle, it could reduce the cost of the system by maintaining an optimal design. 


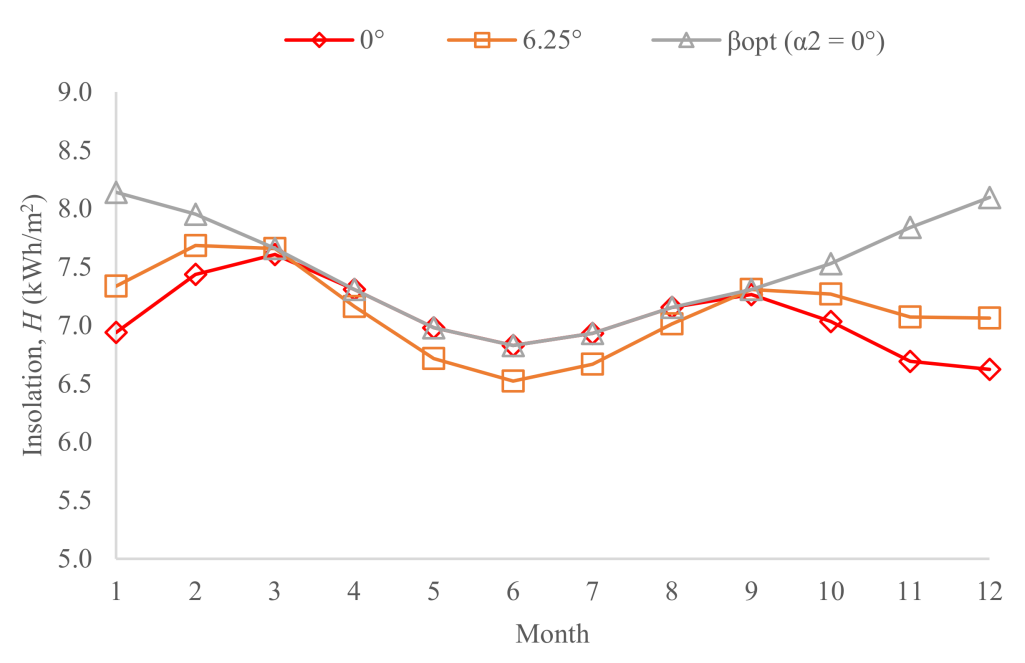

Figure 12. Monthly insolation, $H\left(\mathrm{kWh} / \mathrm{m}^{2}\right)$.

\subsection{Collector Positioned at Optimum Tilt Angle with Variation of Orientation}

In this subsection, there are only two variations of monthly tilt angle, which are $\beta_{\text {opt }}$ $\left(\alpha_{2}=0^{\circ}\right)$ and $\beta_{\text {opt }}\left(\alpha_{2}=0^{\circ}\right.$ and $\left.180^{\circ}\right)$, as shown in Table 9 below. From January to March and September to December, the tilt angle, and the orientation of $\beta_{\mathrm{opt}}\left(\alpha_{2}=0^{\circ}\right)$ and $\beta_{\mathrm{opt}}$ $\left(\alpha_{2}=0^{\circ}\right.$ and $\left.180^{\circ}\right)$, are the same. However, the negative sign of $\beta_{\text {opt }}\left(\alpha_{2}=0^{\circ} \& 180^{\circ}\right)$ from April to August indicates that the collector is positioned facing due north $\left(\alpha_{2}=180^{\circ}\right)$. The insolation per year for a collector positioned at $\beta_{\text {opt }}\left(\alpha_{2}=0^{\circ}\right)$ and $\beta_{\text {opt }}\left(\alpha_{2}=0^{\circ} \& 180^{\circ}\right)$ are $2728.41 \mathrm{kWh} / \mathrm{m}^{2}$ and $2772.38 \mathrm{kWh} / \mathrm{m}^{2}$, respectively.

Table 9. Monthly optimum tilt angle, $\beta_{\text {opt }}$.

\begin{tabular}{|c|c|c|c|c|}
\hline Month & $\begin{array}{c}\beta o p t \\
\left(\alpha_{2}=0^{\circ}\right)\end{array}$ & $\begin{array}{c}\text { H of } \beta \text { opt } \\
\left(\alpha_{2}=0^{\circ}\right) \\
\left(\mathrm{kWh} / \mathrm{m}^{2} \text { Per Month) }\right.\end{array}$ & $\begin{array}{c}\beta o p t \\
\left(\alpha_{2}=0^{\circ} \&\right. \\
\left.180^{\circ}\right)\end{array}$ & $\begin{array}{c}\text { H of } \beta \text { opt } \\
\left(\alpha_{2}=0^{\circ} \& 180^{\circ}\right) \\
\left(\mathrm{kWh} / \mathrm{m}^{2} \text { Per Month) }\right.\end{array}$ \\
\hline 1 or $\operatorname{Jan}(N=21)$ & $33.63^{\circ}$ & 252.35 & $33.63^{\circ}$ & 252.35 \\
\hline 2 or Feb $(N=52)$ & $21.39^{\circ}$ & 222.68 & $21.39^{\circ}$ & 222.68 \\
\hline 3 or $\operatorname{Mar}(N=80)$ & $7.23^{\circ}$ & 237.46 & $7.23^{\circ}$ & 237.46 \\
\hline 4 or $\operatorname{Apr}(N=111)$ & $0^{\circ}$ & 219.25 & $-9.21^{\circ}$ & 221.66 \\
\hline 5 or May $(N=141)$ & $0^{\circ}$ & 216.38 & $-20.00^{\circ}$ & 227.91 \\
\hline 6 or June $(N=172)$ & $0^{\circ}$ & 204.84 & $-23.93^{\circ}$ & 220.69 \\
\hline 7 or Jul $(N=202)$ & $0^{\circ}$ & 214.89 & $-20.31^{\circ}$ & 226.60 \\
\hline 8 or $\operatorname{Aug}(N=233)$ & $0^{\circ}$ & 221.77 & $-9.29^{\circ}$ & 224.22 \\
\hline 9 or Sept $(N=264)$ & $6.87^{\circ}$ & 219.25 & $6.87^{\circ}$ & 219.25 \\
\hline 10 or Oct $(N=294)$ & $22.49^{\circ}$ & 233.39 & $22.49^{\circ}$ & 233.39 \\
\hline 11 or $\operatorname{Nov}(N=325)$ & $33.55^{\circ}$ & 235.18 & $33.55^{\circ}$ & 235.18 \\
\hline 12 or $\operatorname{Dec}(N=355)$ & $37.39^{\circ}$ & 250.98 & $37.39^{\circ}$ & 250.98 \\
\hline $\begin{array}{l}\text { Total insolation, } H \\
\left(\mathrm{kWh} / \mathrm{m}^{2} \text { per year) }\right.\end{array}$ & - & 2728.41 & - & 2772.38 \\
\hline
\end{tabular}

The insolation per year for a collector positioned at $\beta_{\text {opt }}\left(\alpha_{2}=0^{\circ}\right)$ and $\beta_{\text {opt }}\left(\alpha_{2}=0^{\circ}\right.$ and $180^{\circ}$ ) are $2728.41 \mathrm{kWh} / \mathrm{m}^{2}$ and $2772.38 \mathrm{kWh} / \mathrm{m}^{2}$, respectively. Based on Figure 13 below, the monthly insolation plotted from April to August illustrates higher values when the collector is positioned at an optimum tilt angle of orientation, $\alpha_{2}=0^{\circ}$ and $180^{\circ}$. The gain 
of insolation for the collector that is positioned at $\beta_{\text {opt }}\left(\alpha_{2}=0^{\circ}\right.$ and $\left.180^{\circ}\right)$ is approximately $43.97 \mathrm{kWh} / \mathrm{m}^{2}$ more per year than the collector positioned at $\beta_{\mathrm{opt}}\left(\alpha_{2}=0^{\circ}\right)$. The collector that is maintained at $\beta_{\mathrm{opt}}$ faced due south $\left(\alpha_{2}=0^{\circ}\right)$ at all times accounted for a loss of insolation of about $4.08 \%$.

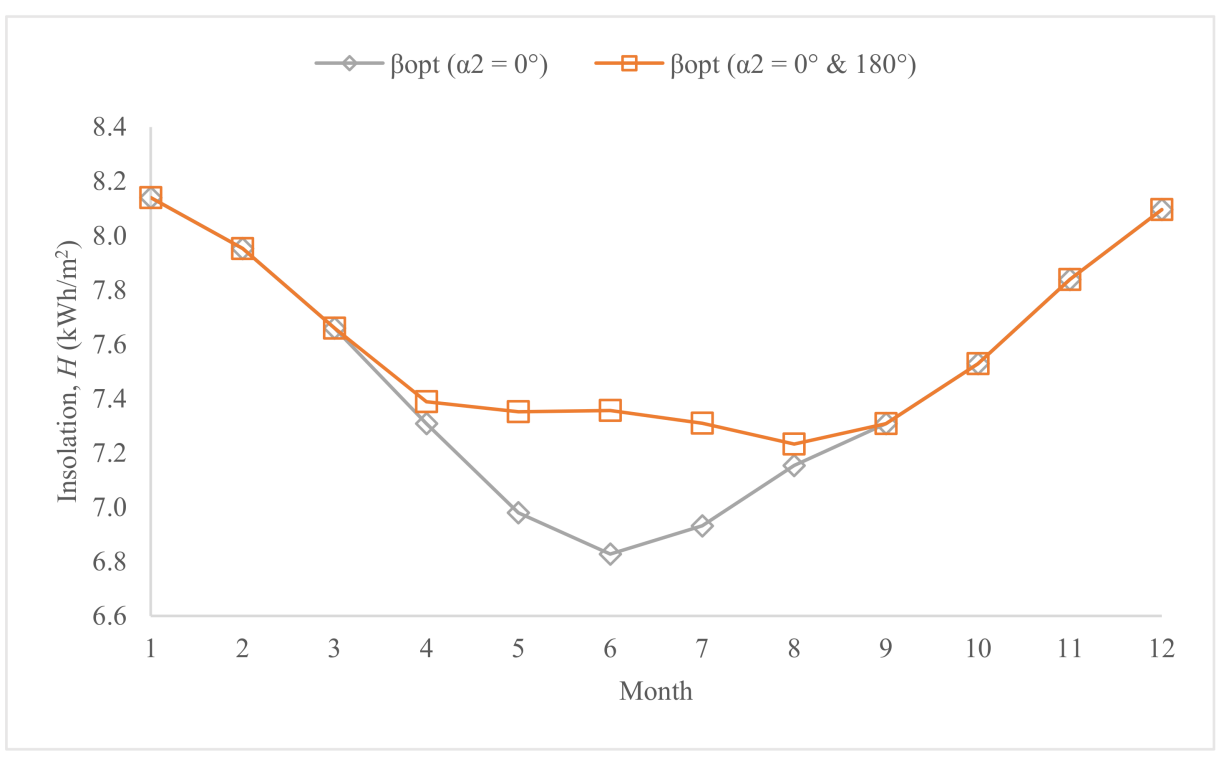

Figure 13. Monthly optimum tilt angle, $\beta_{\mathrm{opt}}$.

This suggests that the orientations of PV modules are equally as crucial as tilt angles. It is more desirable to position the collector facing north from April to August at its respective optimum tilt angle to capture the maximum amount of solar radiation for electricity generation. Besides, it has been proven that a collector located in the northern hemisphere does not always have to be oriented to the south.

\subsection{Collector Positioned at Fixed Tilt Angle and Variation of Orientation}

It is rather impractical to change the collector tilt angle and orientation every month. This incurs tedious mechanical work that could add more to the cost of solar energy system ownership. Hence, for the collector to be kept in a fixed position, the selected tilt angle and its orientation must capture the most from the solar radiation.

Based on Figure 14, the plotted graph illustrates the average yearly insolation, $H$, of a collector positioned at $\beta_{2}=0^{\circ}$ to $20^{\circ}$ of orientation facing due south $\left(\alpha_{2}=0^{\circ}\right)$ and facing due north $\left(\alpha_{2}=180^{\circ}\right)$. Further calculation of $\beta_{2}>20^{\circ}$ will result in lower $H$ for both orientations, and hits the lowest point at $\beta_{2}=90^{\circ}$ (the collector is kept perpendicular with respect to the ground). When the collector is oriented facing due south, its corresponding $H$ value is always higher than when the collector is oriented facing due north. This is only true for collector tilt angle, $1^{\circ} \leq \beta_{2} \leq 90^{\circ}$, excluding $\beta_{2}=0^{\circ}$ (where the collector is kept in horizontal position and $H^{\prime}$ s value are the same). For the arrangement where the collector is oriented facing due south $\left(\alpha_{2}=0^{\circ}\right)$, the collector tilt angle $\beta_{2}=8.05^{\circ}$ provides the highest yearly insolation of $2599.58 \mathrm{kWh} / \mathrm{m}^{2}$. 


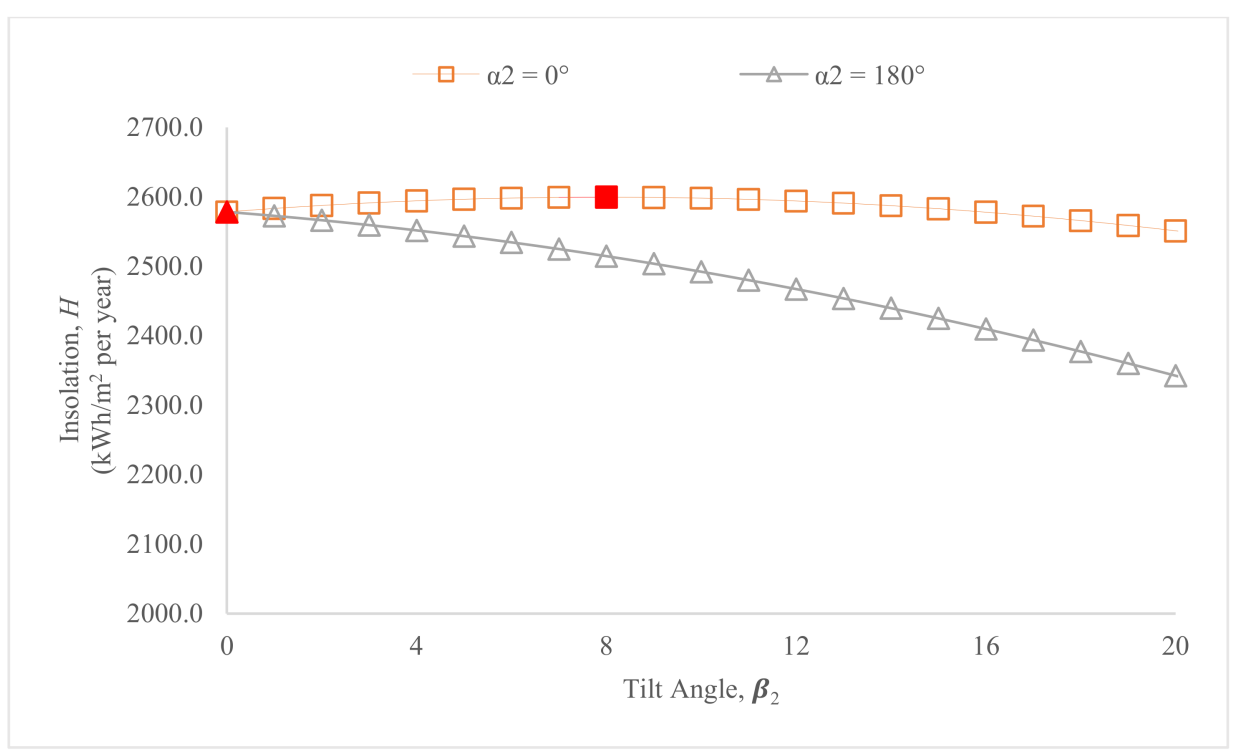

Figure 14. Yearly average insolation, $H$, of orientation facing due south $\left(\alpha_{2}=0^{\circ}\right)$ and facing due north $\left(\alpha_{2}=180^{\circ}\right)$.

Meanwhile, for the collector that is oriented facing due north $\left(\alpha_{2}=180^{\circ}\right)$, the highest insolation of $2578.26 \mathrm{kWh} / \mathrm{m}^{2}$ per year is given by collector tilt angle $\beta_{2}=0^{\circ}$. As the value of $H$ is the highest, the data suggest that the collector tilt angle $\beta_{2}=8.05^{\circ}$ oriented facing due south will be the best option at EPLISSI. Therefore, if the collector's position and configuration should always be kept the same, this angle should be fixed throughout the lifetime of the solar PV system to ensure the most optimal performance.

Apart from that, as mentioned before by Hertzog [37], keeping the collector tilted with respect to the installation location's latitude, $\mathrm{L}$, will cause maximum solar radiation to be captured. However, that is not the case for this study. Based on Figure 15 below, it is illustrated that when the collector is tilted at $\beta_{2}=6.25^{\circ}$, it provides higher average daily insolation in the months from January to March and September to December. In turn, when the collector is tilted at $\beta_{2}=8.05^{\circ}$, it provides higher average daily insolation from April to August. The percentage of gain when the collector is positioned at $\beta_{2}=8.05^{\circ}$ rather than at $\beta_{2}=6.25^{\circ}$ throughout the year is $0.04 \%$. Although this percentage indicates a small quantity, in a period of 30 years (the standard maximum life span of a solar PV system according to Richardson [64]), it could contribute losses of up to $29,000 \mathrm{Wh} / \mathrm{m}^{2}$. Hence, again, tilting the collector surface at $\beta_{2}=8.05^{\circ}$ oriented facing due south will consequently help to provide high $H$ values by capturing the maximum solar radiation. This outcome further proves that for a given condition where the collector is located in the northern hemisphere (the tilt angle need to be maintained at the same position over the year), it has to be oriented facing south for the insolation to be at the maximum value.

Lastly, another finding from the theoretical calculation shows that for a collector that has to be fixed facing due south in January to March and September to December and to be fixed facing due north in April to August at EPLISSI, the collector tilt angle should be fixed at $\beta_{2}=24^{\circ}\left(\alpha_{2}=0^{\circ}\right.$, i.e., south $)$ and $\beta_{2}=17^{\circ}\left(\alpha_{2}=180^{\circ}\right.$, i.e., north $)$, respectively. This will further help the solar PV system to operate more efficiently. By doing so, it provides the yearly insolation value of $2737.96 \mathrm{kWh} / \mathrm{m}^{2}$. That is $138.38 \mathrm{kWh} / \mathrm{m}^{2}$ per year, or $5.32 \%$ more gain as compared to tilting the collector at a fixed angle of $\beta_{2}=8.05^{\circ}\left(\alpha_{2}=0^{\circ}\right)$. 


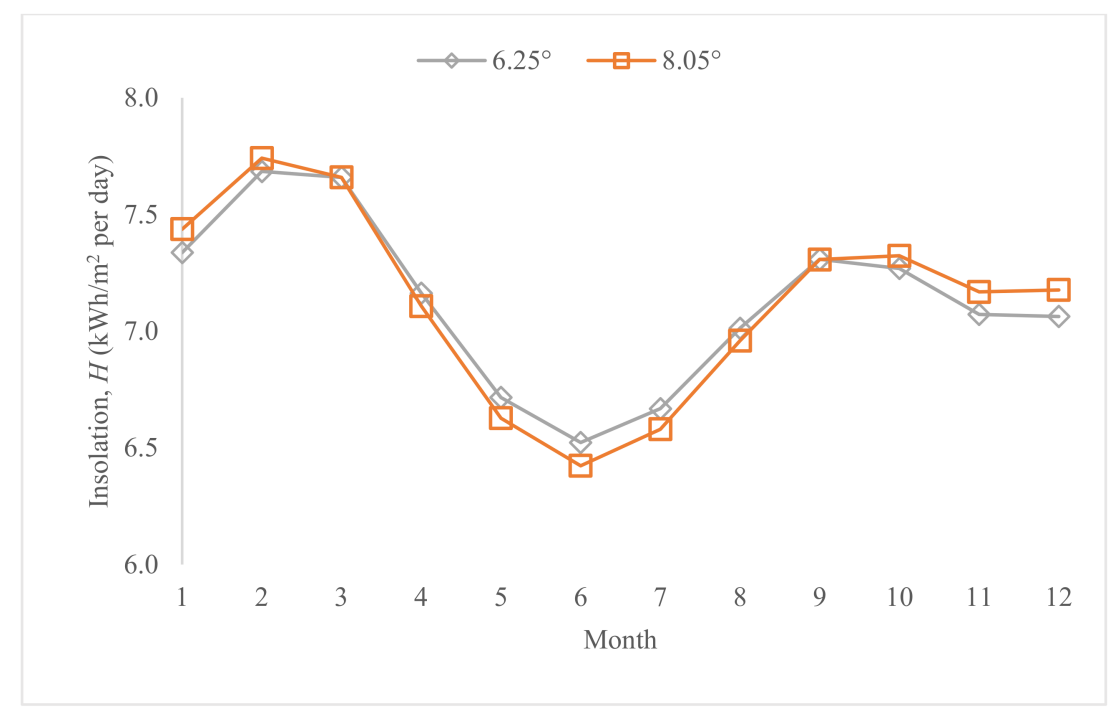

Figure 15. Daily average insolation, $H$, of $\beta_{2}=6.25^{\circ}$ and $\beta_{2}=8.05^{\circ}$.

\section{Conclusions}

The amount of PV energy output generated is influenced by the solar irradiation incident on the collector or PV module surface. The following conclusion in the case of EPLISSI in Sabah, Malaysia, can be drawn, as suggested by the results:

1. The Tian isotropic model is the preferred way for approximating insolation. It has been proven to have the lowest difference among all models, and it has a close agreement with the result of the optimum tilt angle provided by GSA 2.3.

2. In the condition where the collector's orientation is kept in facing due south position throughout the year, the collector should be tilted at various values of $\beta_{\text {opt }}$ according to the month of the year (Section 3.2).

3. Meanwhile, in the condition where both the tilt angle and orientation could be adjusted throughout the year, $\beta_{\mathrm{opt}}\left(\alpha_{2}=0^{\circ}\right.$ and $\left.180^{\circ}\right)$ could provide maximum insolation (Section 3.3).

4. The collector should be positioned at $\beta_{2}=8.05^{\circ}$ if the conditions of both the tilt angle and orientation (facing due south) are fixed.

5. Lastly, in the case where the collector needs to be fixed facing due south from January to March and from September to December, and facing due north from April to August at EPLISSI, the collector tilt angle of $\beta_{2}=24^{\circ}\left(\alpha_{2}=0^{\circ}\right.$, i.e., south $)$ and $\beta_{2}=17^{\circ}$ $\left(\alpha_{2}=180^{\circ}\right.$, i.e., north), respectively, should be used.

6. As verified in the study, the difference in PV power output data between the empirical models and GSA 2.3 (online PV simulation model) is considered acceptable. Without the comprehensive weather data similar to those being used in Solargis, an error in the order of $30 \%$ (in the range of $31 \%$ to $32 \%$ ) should be expected, as shown in the data presented from Section 3.1 .

Author Contributions: Conceptualisation, M.E.M., W.K.M. and M.A.I.; methodology, M.E.M. and W.K.M.; validation, M.A.I., Y.Y.F. and A.E.A.; resources, M.A.R., M.A.I., W.K.M. and M.E.M.; writingoriginal draft preparation, M.E.M.; writing-review and editing, W.K.M., A.F. and A.E.A.; visualisation, W.K.M., A.F. and M.E.M.; supervision, W.K.M., A.F., M.A.I., Y.Y.F. and M.A.R.; funding acquisition, W.K.M. and M.A.I. All authors have read and agreed to the published version of the manuscript.

Funding: This work was supported by research grants from Universiti Malaysia Sabah (UMS) and Malaysia Ministry of Higher Education (MOHE), namely, SDK0121-2019 and FRG0508-1/2019.

Institutional Review Board Statement: Not applicable.

Informed Consent Statement: Not applicable. 
Data Availability Statement: Data sharing not applicable.

Acknowledgments: The authors would like to thank Universiti Malaysia Sabah for the research grant allocated (SDK0121-2019). Special appreciation is also credited to the Malaysian Ministry of Higher Education (MOHE) for the Fundamental Research Grant Scheme (FRG0508-1/2019).

Conflicts of Interest: The authors declare no conflict of interest.

\section{Nomenclature}

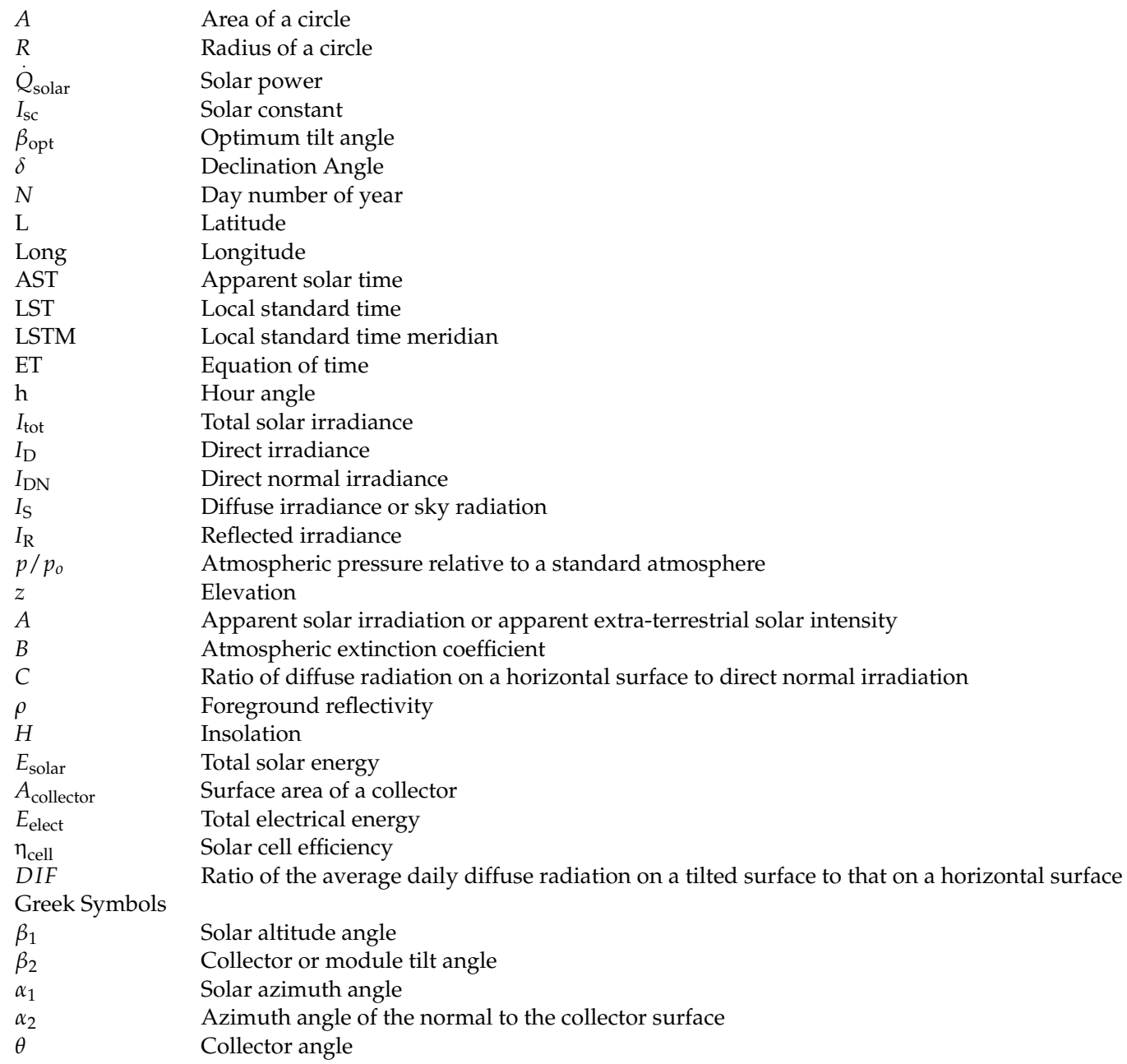

\section{References}

1. Seshie, Y.M.; N’Tsoukpoe, K.E.; Neveu, P.; Coulibaly, Y.; Azoumah, Y.K. Small scale concentrating solar plants for rural electrification. Renew. Sustain. Energy Rev. 2018, 90, 195-209. [CrossRef]

2. U.S. Energy Information Administration. Today in Energy. 2017. Available online: https://www.eia.gov/todayinenergy/detail. php?id=33812 (accessed on 11 October 2020).

3. International Energy Agency. The Latest Trends in Energy and Emissions in 2018; Global Energy and $\mathrm{CO}_{2}$ Status Report 2019; International Energy Agency: Paris, France, 2019.

4. International Energy Agency. Global Energy Review 2020-The Impacts of the Covid-19 Crisis on Global Energy Demand and Carbon Dioxide Emissions. 2020. Available online: https://www.iea.org/reports/global-energy-review-2020/renewables (accessed on 11 October 2020).

5. Shahzad, U. The need for renewable energy sources. Inform. Technol. Electr. Eng. 2015, 4, 16-19.

6. Gielen, D.; Boshell, F.; Saygin, D.; Bazilian, M.D.; Wagner, N.; Gorini, R. The role of renewable energy in the global energy transformation. Energy Strategy Rev. 2019, 24, 38-50. [CrossRef]

7. Malkawi, D.S.; Tamimi, A.I. Comparison of phase change material for thermal analysis of a passive hydronic solar system. J. Energy Storage 2021, 33, 102069. [CrossRef]

8. Punniakodi, B.M.S.; Senthil, R. A review on container geometry and orientations of phase change materials for solar thermal systems. J. Energy Storage 2021, 36, 102452. [CrossRef] 
9. Da Rosa, A.V.; Ordóñez, J.C. Chapter 14-Photovoltaic converters. In Fundamentals of Renewable Energy Processes, 4th ed.; Academic Press: Oxford, UK, 2021; pp. 629-718.

10. Oró, E.; Gil, A.; Gracia, A.; Boer, D.; Cabeza, L.F. Comparative life cycle assessment of thermal energy storage systems for solar power plants. Renew. Energy 2012, 44, 7. [CrossRef]

11. Jayaraman, K.; Paramasivan, L.; Kiumarsi, S. Reasons for low penetration on the purchase of photovoltaic (PV) panel system among Malaysian landed property owners. Renew. Sustain. Energy Rev. 2017, 80, 562-571. [CrossRef]

12. Renewable Energy Policy Network for the 21st Century. In Renewables 2019 Global Status Report; REN21: Paris, France, 2019.

13. Parikh, A. Share of Solar \& Wind Rose Despite Depressed Global Power Demand Amid Pandemic: IEA. 2020. Available online: https://mercomindia.com/share-of-solar-and-wind-rose/ (accessed on 11 October 2020).

14. Saidur, R.; Jazi, G.B.; Mekhlif, S.; Jameel, M. Exergy analysis of solar energy applications. Renew. Sustain. Energy Rev. 2012, 16, 7. [CrossRef]

15. Energysage. Should You Install a Solar Battery for Home Use? 2020. Available online: https://www.energysage.com/solar/ solar-energy-storage/benefits-of-solar-batteries / (accessed on 4 May 2021).

16. Samsudin, M.S.N.; Rahman, M.M.; Wahid, M.A. Power generation sources in malaysia: Status and prospects for sustainable development. Adv. Rev. Sci. Res. 2016, 25, 18.

17. Ahmad, N.A.; Byrd, H. Empowering distributed solar PV energy for Malaysian rural housing: Towards energy security and equitability of rural communities. Int. J. Renew. Energy Dev. 2013, 2, 10. [CrossRef]

18. Halabi, L.M.; Mekhilef, S.; Olatomiwa, L.; Hazelton, J. Performance analysis of hybrid PV/diesel/battery system using HOMER: A case study Sabah, Malaysia. Energy Convers. Manag. 2017, 144, 18. [CrossRef]

19. Izadyar, N.; Ong, H.C.; Chong, W.T.; Mojumder, J.C.; Leong, K.Y. Investigation of potential hybrid renewable energy at various rural areas in Malaysia. J. Clean. Prod. 2016, 139, 13. [CrossRef]

20. Jäger, K.; Isabella, O.; Smets, A.H.M.; Swaaij, R.A.C.M.M.V.; Zeman, M. Solar Energy Fundamentals, Technology, and Systems; UIT Cambridge: Cambridge, UK, 2014.

21. Salameh, T.; Abdelkareem, M.A.; Olabi, A.G.; Sayed, E.T.; Al-Chaderchi, M.; Rezk, H. Integrated standalone hybrid solar PV, fuel cell and diesel generator power system for battery or supercapacitor storage systems in Khorfakkan, United Arab Emirates. Int. J. Hydrog. Energy 2021, 46, 6014-6027. [CrossRef]

22. Burke, M.J.; Stephens, J.C. Political power and renewable energy futures: A critical review. Energy Res. Soc. Sci. 2018, 35, 78-93. [CrossRef]

23. Ho, S.; Abraham, L.; Edmund, C.O.; Urrego, L.R. Investigation of solar energy: The case study in Malaysia, Indonesia, Colombia and Nigeria. Int. J. Renew. Energy Res. 2019, 9, 10.

24. Markos, F.M.; Sentian, J. Potential of solar energy in Kota Kinabalu, Sabah: An estimate using a photovoltaic system model. J. Phys. 2016, 710, 11. [CrossRef]

25. World Bank Group. Global Solar Atlas Report Kota Belud. 2019. Available online: https://globalsolaratlas.info/map (accessed on 11 October 2020).

26. Global Solar Atlas. Map and Data Downloads. Available online: https://globalsolaratlas.info/download/malaysia (accessed on 20 November 2020).

27. Abdallah, R.; Juaidi, A.; Salameh, A.F.; Agugliaro, F.M. Estimating the optimum tilt angles for south-facing surfaces in Palestine. Energies 2020, 13, 623. [CrossRef]

28. Awasthi, A.; Shukla, A.K.; Murali Manohar, S.R.; Dondariya, C.; Shukla, K.N.; Porwal, D.; Richhariya, G. Review on sun tracking technology in solar PV system. Energy Rep. 2020, 6, 392-405. [CrossRef]

29. Khatib, T.; Muhsen, D.H. Optimal sizing of standalone photovoltaic system using improved performance model and optimisation algorithm. Sustainability 2020, 12, 2233. [CrossRef]

30. Kasirajan, S.; Tan, K.T.; Leong, W.Y. Investigation on tilt angle calculation and irradiation on solar panels. Int. J. Eng. Technol. 2019, 8, 75-78.

31. Office of Energy Efficiency and Renewable Energy. Solar Radiation Basics. 2020. Available online: https://www.energy.gov/ eere/solar/solar-radiation-basics (accessed on 5 May 2021).

32. Li, D.; Lam, T. Determining the optimum tilt angle and orientation for solar energy collection based on measured solar radiance data. Int. J. Photoenergy 2007, 8, 85402. [CrossRef]

33. Shukla, K.N.; Rangnekarb, S.; Sudhakar, K. Comparative study of isotropic and anisotropic sky models to estimate solar radiation incident on tilted surface: A case study for Bhopal, India. Energy Rep. 2015, 1, 96-103. [CrossRef]

34. Hailu, G.; Fung, A.S. Optimum tilt angle and orientation of photovoltaic thermal system for application in greater Toronto area, Canada. Sustainability 2019, 11, 6443. [CrossRef]

35. Kamali, G.A.; Moradi, I.; Khalili, A. Estimating solar radiation on tilted surfaces with various orientations: A study case in Karaj (Iran). Theor. Appl. Climatol. 2006, 84, 235-241. [CrossRef]

36. Mian, G.; Haixiang, Z.; Shengyu, G.; Tingji, C.; Jing, X.; Lexiang, C.; Zhinong, W.; Guoqiang, S. Optimal tilt angle and orientation of photovoltaic modules using HS algorithm in different climates of China. Appl. Sci. 2017, 7, 1028.

37. Hertzog, P.E.; Swart, A.J. Optimum tilt angles for PV modules in a semi arid region of the Southern hemisphere. Int. J. Eng. Technol. 2018, 7, 290-297. [CrossRef] 
38. Soulayman, S.; Mohammad, M.; Salah, N. Solar receivers optimum tilt angle at southern hemisphere. Open Access Lib. J. 2016,3 , 1. [CrossRef]

39. Khatib, T.; Mohamed, A.; Mahmoud, M.; Sopian, K. Optimisation of the tilt angle of solar panels for Malaysia. Energy Sour. 2015, 37, 606-613. [CrossRef]

40. Khai, M.N.; Nor Mariah, A.; Othman, I.; Mohd Zainal Abidin, A.K. Assessment of solar radiation on diversely oriented surfaces and optimum tilts for solar absorbers in Malaysian tropical latitude. Int. J. Energy Environ. Eng. 2014, 5, 1-13.

41. Fadaeenejad, M.; Mohd Amran, M.R.; Fadaeenejad, M.; Mahdi, Z.; Zohreh, G. Optimisation and comparison analysis for application of PV panels in three villages. Energy Sci. Eng. 2014, 3, 145-152. [CrossRef]

42. Muhida, R.M.A.; Kassim, J.P.S.; Eusuf, M.A.; Sutjipto, A.G.; Afzeri, A. A simulation method to find the optimal design of photovoltaic home system in Malaysia, case study: A building integrated photovoltaic in Putra Jaya. World Acad. Sci. Eng. Technol. 2009, 53, 694-698.

43. Sunderan, P.; Adibah, M.I.; Singh, B.; Norani, M.M. Optimum tilt angle and orientation of stand-alone photovoltaic electricity generation systems for rural electrification. Appl. Sci. 2011, 11, 1219-1224. [CrossRef]

44. Elhassan, Z.A.M.; Zain, M.F.M.; Sopian, K.; Awadalla, A. Output energy of photovoltaic module directed at optimum slope angle in Kuala Lumpur, Malaysia. Appl. Sci. 2011, 6, 104-109. [CrossRef]

45. Daut, M.I.I.; Irwan, Y.M.; Gomesh, N.; Rosnazri, N.S. Clear sky global solar irradiance on tilt angles of photovoltaic module in Perlis, Northern Malaysia. In Proceedings of the International Conference on Electrical, Control and Computer Engineering, Kuantan, Malaysia, 21-22 June 2011.

46. Khatib, T.; Mohamed, A.; Sopian, K. Optimisation of a PV/wind micro-grid for rural housing electrification using a hybrid iterative/genetic algorithm: Case study of Kuala Terengganu, Malaysia. Energy Build. 2012, 47, 321-331. [CrossRef]

47. Omidreza, S.K.S.; Elhab, B.; Ruslan, M.H.; Asim, N. Optimal solar panels' tilt angles and orientations in Kuala Lumpur, Malaysia. In Proceedings of the 1st WSEAS International Conference on Energy and Environment Technologies and Equipment (EEETE' 12), Zlin, Czech Republic, 20-22 September 2012.

48. Hussein, A.K.; Miqdam, T.C.; Ali, H.A.; Kavish, M. Effect of shadow on the performance of solar photovoltaic. In Mediterranean Green Buildings \& Renewable Energy; Springer: Cham, Switzerland, 2015.

49. Weather Spark. Average Weather in Kota Belud, Malaysia. Available online: https://weatherspark.com/y/130293/AverageWeather-in-Kota-Belud-Malaysia-Year-Round (accessed on 19 November 2020).

50. World Weather Online. Kota Belud Monthly Climate Averages. Available online: https://www.worldweatheronline.com/kotabelud-weather-averages/sabah/my.aspx (accessed on 19 November 2020).

51. Solargis. Methodology—Solar Radiation Modeling. Available online: https://solargis.com/docs/methodology/solar-radiationmodeling (accessed on 3 May 2021).

52. Ineichen, P. Long Term Satellite Hourly, Daily and Monthly Global, Beam and Diffuse Irradiance Validation. Interannual Variability Analysis; Adapted to CM-SAF Product from the IEA 2013 Report; IEA: Paris, France, 2014.

53. Global Solar Atlas. About Global Solar Atlas. Available online: https://globalsolaratlas.info/support/about (accessed on 15 October 2020).

54. Solargis. Documentation: Methodology. Available online: https://solargis.com/docs/methodology (accessed on 4 May 2021).

55. Duffie, J.; Beckman, W. Solar Engineering of Thermal Processes, 2nd ed.; John Wiley and Sons: New York, NY, USA, 1991.

56. Hagen, K.D. Introduction to Renewable Energy for Engineers; Pearson: London, UK, 2016.

57. Holbert, K.E. Solar Calculations. 2007. Available online: http:/ /holbert.faculty.asu.edu/eee463/SolarCalcs.pdf (accessed on 11 October 2020).

58. Lunde, P.J. Solar Thermal Engineering Space Heating and Hot Water Systems; John Wiley and Sons: New York, NY, USA, 1980.

59. Liu, B.Y.H.; Jordan, R.C. The Interrelationship and Characteristic Distribution of Direct, Diffuse, and Total Solar Radiation. Solar Energy 1960, 4, 1-19. [CrossRef]

60. Kotak, Y.; Gul, M.; Muneer, T.; Ivanova, S. Investigating the impact of ground albedo on the performance of PV systems. In Proceedings of the CIBSE Technical Symposium, London, UK, 16-17 April 2015.

61. Koronakis, P.S. On the choice of the angle of tilt for south facing solar collectors in the Athens basin area. Solar Energy 1986, 36, 217-225. [CrossRef]

62. Badescu, V. A new kind of cloudy sky model to compute instantaneous values of diffuse and global solar irradiance. Theor. Appl. Climatol. 2002, 72, 127-136. [CrossRef]

63. Tian, Y.Q.; Davies-Colley, R.J.; Gonga, P.; Thorrold, B.W. Estimating solar radiation on slopes of arbitrary aspect. Agricult. For. Meteorol. 2001, 1, 67-74. [CrossRef]

64. Richardson, L. How Long Do Solar Panels Last? 2020. Available online: https://news.energysage.com/how-long-do-solarpanels-last/ (accessed on 16 October 2020). 